http://kitaibelia.unideb.hu/

ISSN 2064-4507 (Online) • ISSN 1219-9672 (Print)

(C) Department of Botany, University of Debrecen, Hungary

25(1): 57-78.; 2020

DOI: $10.17542 /$ kit.25.57

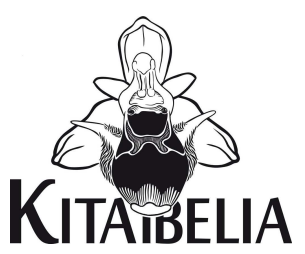

\title{
A Csepel-sziget fehérnyár-ligetei (Senecioni sarracenici-Populetum albae Kevey in Borhidi \& Kevey 1996)
}

\author{
KEVEY Balázs \\ Pécsi Tudományegyetem, Ökológiai Tanszék; 7624 Pécs, Ifjúság u. 6.; keveyb@gamma.ttk.pte.hu

\begin{abstract}
White poplar riparian forests on the Csepel-sziget, Middle-Hungary
\end{abstract} \\ (Senecioni sarracenici-Populetum albae Kevey in Borhidi \& Kevey 1996)
}

\begin{abstract}
In this paper the white poplar riparian forests (Senecioni sarracenici-Populetum albae) growing on the Csepel-sziget and its vicinity are described and characterized based on 25 phytosociological relevés. These communities grow on loose fluvial sand and raw alluvial soils on the elevated parts of the lower river floodplain. They can readily be distinguished from willow gallery forests (Leucojo aestivi-Salicetum albae) which have no shrub layers and grow in habitats 1-1.5 $\mathrm{m}$ below the level of poplar forests on rather heavy and muddy soils. They differ also from the oak-ash-elm forests (Scillo vindobonensis-Ulmetum) growing in the upper floodplain. Certain - partly submontane - plants that are rare or completely absent in other parts of the Great Hungarian Plains may also occur in them, such as Anemone ranunculoides, Carex remota, Clematis recta, Crataegus $\times$ degenii, Crataegus nigra, Epipactis helleborine, Equisetum hyemale, Galanthus nivalis, Lathraea squamaria, Leucojum aestivum, Paris quadrifolia, Scilla vindobonensis, Vitis sylvestris. This association is classified in the sub-alliance Populenion nigro-albae Kevey 2008 in the syntaxonomical system.
\end{abstract}

Keywords: Hungarian Plains, multivariate analyses, riparian forest, Syntaxonomy

Összefoglalás - Jelen tanulmány a Magyarország középső részén levő Duna-ártér fehérnyár-ligeteinek (Senecioni sarracenici-Populetum albae) társulási viszonyait mutatja be 25 cönológiai felvétel alapján. Laza öntéshomok alapkőzeten és nyers öntéstalajon kialakult állományaik az alacsony ártér viszonylag magasabb szintjeit foglalják el. Faji összetételükkel és fejlett cserjeszintjükkel jól elkülöníthetők a mintegy 1-1,5 m-rel mélyebben fekvő, kötött és iszapos talajú, cserjeszint nélküli fúzligetektől (Leucojo aestivi-Salicetum albae), valamint a magasabb ártéri szinten fejlődő tölgy-kőris-szil ligetektől (Scillo vindobonensis-Ulmetum). Aljnövényzetükben egyes - részben szubmontán jellegű - növények is megjelenhetnek, amelyek az Alföld egyéb tájain ritkák, vagy teljesen hiányoznak: Anemone ranunculoides, Carex remota, Clematis recta, Crataegus $\times$ degenii, Crataegus nigra, Epipactis helleborine, Equisetum hyemale, Galanthus nivalis, Lathraea squamaria, Leucojum aestivum, Paris quadrifolia, Scilla vindobonensis, Vitis sylvestris. Az asszociáció a szüntaxonómiai rendszer „Populenion nigro-albae Kevey 2008" alcsoportjába helyezhető.

Kulcsszavak: ligeterdő, Magyar-Alföld, sokváltozós elemzések, szüntaxonómia

\section{Bevezetés}

Mint ismeretes, a hazai puhafás ligeterdeinket sokáig fűz-nyár ligeterdőként Salicetum albaefragilis néven tartottuk nyilván (vö. SimoN 1957, Soó 1958, 1964, 1973, 1980). Később bizo- 
nyítást nyert, hogy e puhafás ligeterdők Magyarországon három asszociációt foglalnak magukba (vö. Kevey 1993, KevEY in BorHIDI \& Kevey 1996, Kevey 2008). Ezek egyike a Szigetközből leírt fehérnyár-liget (Senecioni sarracenici-Populetum albae Kevey in Borhidi \& Kevey 1996), amely később nemcsak a Duna-vidék egyéb tájain (Csepel-sziget: Kevey ined., KEvEY \& HuSZÁR 1999; Sárköz: TóTH 1958, Kevey ined.; Mohácsi-sziget: KeVEY 2019), hanem a Dráva (vö. Kevey 2008, Kevey \& Tóth 2006), a Mura (Kevey 2014), a Rába (Kevey \& BaRna 2018), a Bodrogköz (Szirmai et al. 2008, Kevey ined.) és a Tisza mellől (KeVEY \& BARNA 2014) is előkerült. Jelen tanulmányban a Csepel-sziget és környékének fehérnyár-ligeteit mutatom be 25 felvétel alapján.

\section{Anyag és módszer}

\section{Kutatási terület jellemzése}

A Csepel-szigeten a fehérnyár-ligetek a Nagy-Duna hullámterén találhatók. Botanikai értelemben ide sorolható a Duna jobb parti hullámtere is, ugyanis egy folyó jobb és bal partjának vegetációja gyakorlatilag azonos. Így ide sorolhatók a Budapest alatti „Háros-sziget”, valamint a Százhalombatta, Ercsi és Rácalmás melletti szigetek fehérnyár-ligetei. A folyami hordalékot elsősorban durva, másutt finom homok képezi. A fehérnyár-ligetek (Senecioni sarracenici-Populetum albae) az alacsony ártér homokos és viszonylag magasabb szintjein találhatók, elkülönülve a mintegy 1-1,5 m-rel mélyebben fekvő és iszapos talajú szinteket borító fehérfűz-ligetektől (Leucojo aestivi-Salicetum albae) (vö. KeveY 1993, 2008). Vizsgált állományaik 95-100 m tengerszint feletti magasság mellett fordulnak elő, laza szerkezetű, homokos, nyers öntéstalajokon.

\section{Alkalmazott módszerek}

A cönológiai felvételek a Zürich-Montpellier növénycönológiai iskola (BECKING 1957, BRAUNBLANQUET 1964) hagyományos kvadrát-módszerével készültek. A felvételek táblázatos öszszeállítása, valamint a karakterfajok csoportrészesedésének és csoporttömegének kiszámítása az „NS” számítógépes programcsomaggal (KEVEY \& HIRMANN 2002) történt. A felvételkészítés és a hagyományos statisztikai számítások - kissé módosított - módszerét korábban részletesen közöltem (KEVEY 2008). A felvételek összehasonlításánál - a SYN-TAX 2000 programcsomag (PODANI 2001) segítségével bináris adatokon alapuló hierarchikus osztályozást, cluster-analízist (hasonlósági index: Baroni-Urbani-Buser; osztályozó módszer: teljes lánc) végeztem. Mivel a Duna folyásirányát tekintve a Csepel-sziget és környéke, a Szigetköz és a Mohácsi-sziget között nagyjából félúton helyezkedik el, ezért a karakterfajok arányát e három tájegység fehérnyár-ligeteinek (Senecioni sarracenici-Populetum albae) viszonylatában vizsgáltam (4. táblázat). A fehérnyár-ligetek és a tölgy-kőris-szil ligetek kapcsolatának tisztázása miatt az összehasonlításba belevontam a Csepel-sziget tölgy-kőris-szil ligeteit (Scillo vindobonensis-Ulmetum Kevey in Borhidi \& Kevey 1996) is.

A fajok esetében KIRÁly (2009), a társulásoknál pedig BorHIDI \& KevEY (1996), KeveY (2008), ill. BORHIDI et al. (2012) nómenklatúráját követem. A társulástani és a karakterfajstatisztikai táblázatok felépítése az újabb eredményekkel (OBERDORFER 1992, MuCINA et al. 1993, BoRHIDI et al. 2012, KEVEY 2008) módosított Soó (1980) féle cönológiai rendszerre épül. A növények cönoszisztematikai besorolásánál is elsősorban Soó $(1964,1966,1968$, 1970, 1973, 1980) Synopsis-ára támaszkodtam, de figyelembe vettem az újabb kutatási eredményeket is (vö. BoRHIDI 1993, 1995, HoRváth et al. 1995, Kevey ined.). 


\section{Eredmények}

\section{Fiziognómia}

A vizsgált fehérnyár-ligetek felső lombkoronaszintje az állomány korától függően 22-30 m magas és közepesen záródó (50-80\%). Állandó (K IV-V) fajai a Populus alba mellett a Populus nigra, a Quercus robur és az Ulmus laevis. Közülük állományalkotó (A-D: 3-4) szerepet csak a Populus alba és a Populus nigra tölt be. Az alsó lombkoronaszint változóan fejlett. Magassága 14-20 m, borítása pedig 20-60\%. Főleg alászorult fák alkotják. Közülük a Populus alba, az Ulmus laevis és az Ulmus minor érhet el nagy állandóságot (K IV-V). Nagyobb tömeget (A-D: 3) az Acer campestre, és az idegenhonos Vitis vulpina képez.

A cserjeszint többnyire erősen fejlett. Magassága 2-4 m, borítása 30-75\%. Állandó (K IV-V) fajai a következők: Acer campestre, Cornus sanguinea, Crataegus monogyna, Euonymus europaeus, Sambucus nigra, Ulmus minor, valamint a tájidegen Acer negundo. Nagyobb tömegben (A-D: 3-4) csak a Sambucus nigra, a Cornus sanguinea, valamint az Acer negundo fordul elő. Az alsó cserjeszint (újulat) borítása 1-30\%. Állandó (K IV-V) fajai a következők: Acer campestre, Cornus sanguinea, Euonymus europaeus, Populus alba, Quercus robur, Rubus caesius, Ulmus minor, Viburnum opulus. Közülük nagyobb borítást (A-D: 3) csak a Rubus caesius ér el.

A gyepszint változóan fejlett (25-90\%). Állandó (K IV-V) fajai a következők: Aristolochia clematitis, Chelidonium majus, Circaea lutetiana, Convallaria majalis, Galeopsis speciosa, Galium aparine, Glechoma hederacea, Leucojum aestivum, Poa trivialis, Polygonatum latifolium, Ranunculus ficaria, Scilla vindobonensis, Symphytum officinale, Urtica dioica, Viola suavis. Fáciest (A-D: 3-5) a Convallaria majalis, az Impatiens noli-tangere, a Leucojum aestivum, a Polygonatum latifolium, a Ranunculus ficaria, a Scilla vindobonensis, valamint az idegenhonos Impatiens parviflora képez (vö. 1. táblázat).

Fajkombináció

\section{Állandósági osztályok eloszlása}

A 25 cönológiai felvétel alapján a társulásban 18 konstans (K V) és 10 szubkonstans (K IV) faj szerepel az alábbiak szerint: - K V: Acer campestre, Cornus sanguinea, Euonymus europaeus, Galium aparine, Glechoma hederacea, Poa trivialis, Polygonatum latifolium, Populus alba, Populus nigra, Quercus robur, $R a-$ nunculus ficaria, Rubus caesius, Scilla vindobonensis, Symphytum officinale, Ulmus laevis, Ulmus minor, Urtica dioica, Viburnum opulus. - K IV: Acer negundo, Aristolochia clematitis, Chelidonium majus, Circaea lutetiana, Convallaria majalis, Crataegus

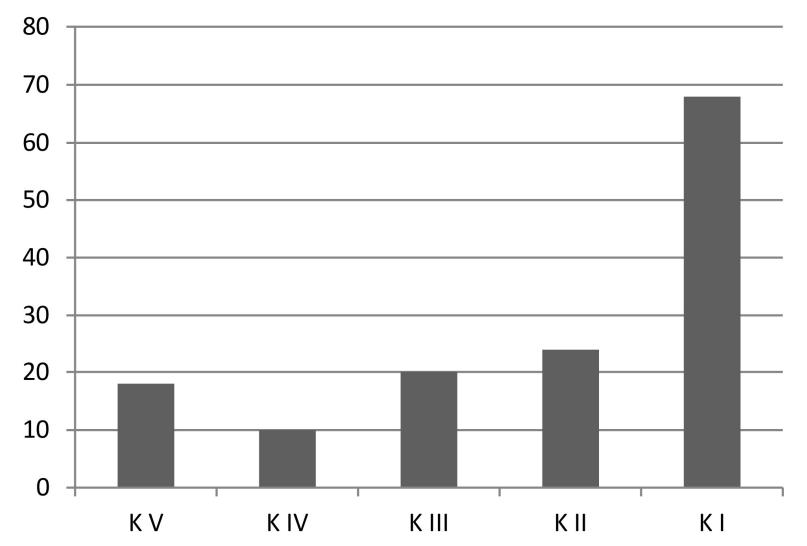

1. ábra Az állandósági osztályok eloszlása;

Fig. 1 Distribution of constancy classes; monogyna, Galeopsis speciosa, Leucojum aestivum, Sambucus nigra, Viola suavis. Ezen kívül 20 akcesszórikus (K III), 24 szubakcesszórikus (K II) és 68 akcidens (K I) faj került elő. Az állandósági osztályok fajszáma tehát az akcidens (K I) fajoktól a szubkonstans (K IV) elemekig csökken, majd a konstans (KV) fajoknál ismét magasabb (vö. 1. táblázat, 1. ábra). 

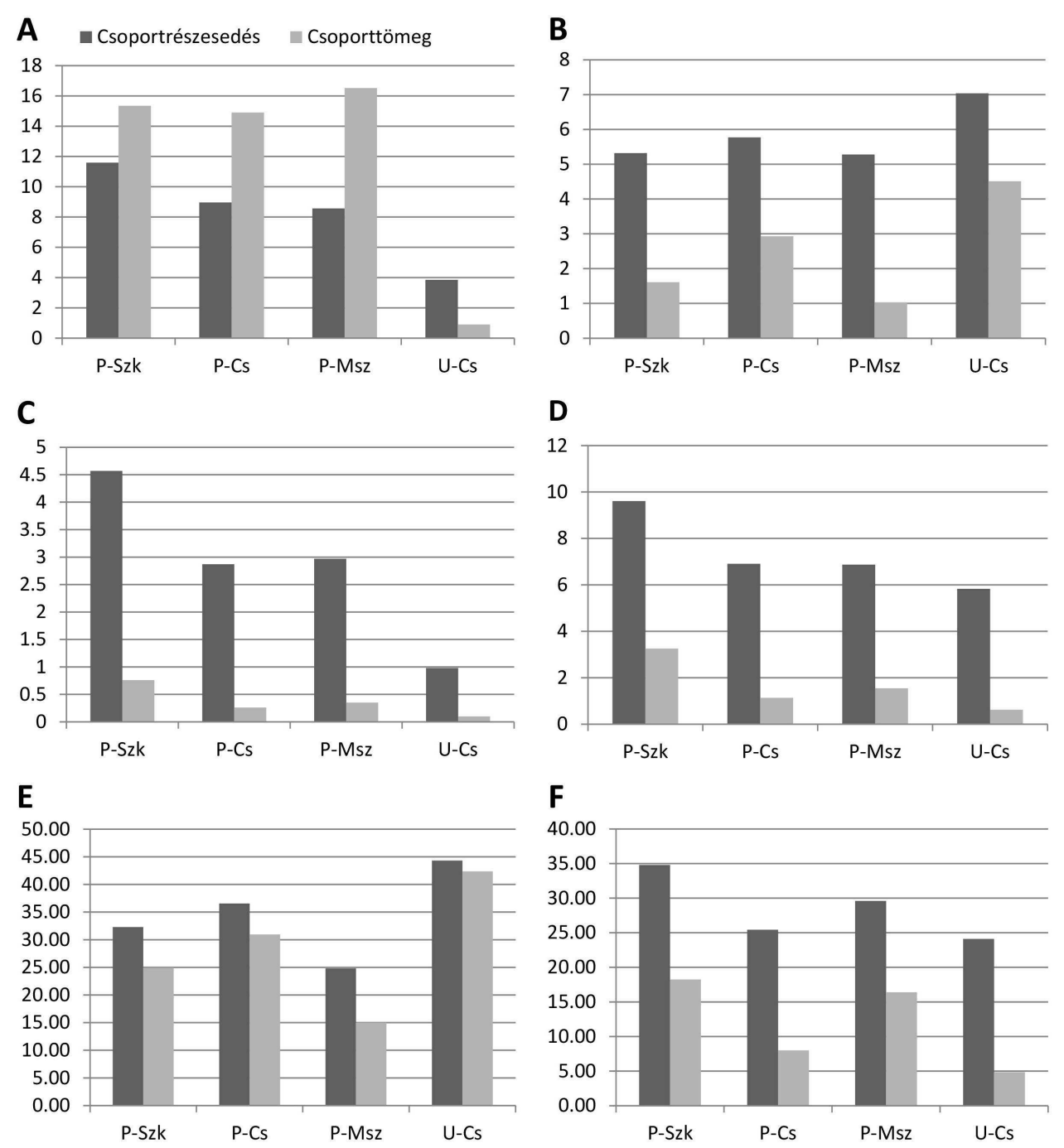

2. ábra A Salicetea purpureae s.l. fajok aránya; B Fagetalia fajok aránya; C Cypero-Phragmitea s.l. fajok aránya; D Galio-Urticetea s.l. fajok aránya; E Generalista fajok (G 4) aránya;

F Zavarástűrő fajok (DT 2) aránya

Fig. 2 A Proportion of species characteristic of the class Salicetea purpureae; B Proportion of species characteristic of the order Fagetalia; C Proportion of species characteristic of the divisio Cypero-

Phragmitea s.l.; D Proportion of species characteristic of the class Galio-Urticetea s.l.; E Proportion of species generalists (G 4); F Proportion of species disturbance tolerants (DT 2)

P-Szk: Senecioni sarracenici-Populetum albae, Szigetköz (KEVEY 2008: 25 felv.)

P-Cs: Senecioni sarracenici-Populetum albae, Csepel-sziget (KEvEY \&HuSZÁR 1999: 10 felv.; Kevey ined.: 15 felv.)

P-Msz: Senecioni sarracenici-Populetum albae, Mohácsi-sziget (Kevey 2017: 25 felv.)

U-Cs: Scillo vindobonensis-Ulmetum, Csepel-sziget (Kevey ined.: 12 felv.)

\section{Karakterfajok aránya}

Mint általában a puhafás ligeterdőkben is, a Salicetea purpureae s.l. (incl. Salicion albae) jellegű elemek a Csepel-szigeten és környékén is fontos szerepet játszanak: - K V: Populus nigra. - K IV: Leucojum aestivum. - K III: Cucubalus baccifer, Humulus lupulus. - K I: Carduus crispus, 
Crataegus nigra, Crataegus $\times$ degenii, Salix alba. A Salicetea purpureae elemek csoportrészesedése a Csepel-sziget térségében és a Mohácsi-szigeten igen hasonló, a Szigetközben viszont magasabb (4. táblázat, 2. ábra A).

Jelentősek a keményfás ligeterdők (Alnion incanae incl. Alnenion glutinosae-incanae) elemei is: - K V: Populus alba, Ulmus laevis, Viburnum opulus. - K III: Carex remota, Fraxinus angustifolia, Rumex sanguineus, Festuca gigantea. - K II: Malus sylvestris, Impatiens nolitangere. - K I: Elymus caninus, Equisetum hyemale, Padus avium, Ribes rubrum, Vitis sylvestris. Arányuk mindhárom tájegységen rendkívül hasonló (4. táblázat).

Nem túlságosan gyakoriak, de fontos szerepet töltenek be a mezofil lomberdei (Fagetalia) elemek is: - K V: Scilla vindobonensis. - K IV: Circaea lutetiana, Galeopsis speciosa. - K III: Galanthus nivalis. - K II: Carex sylvatica, Hedera helix, Moehringia trinervia, Stachys sylvatica. - K I: Acer platanoides, Acer pseudo-platanus, Anemone ranunculoides, Cerasus avium, Epipactis helleborine, Gagea lutea, Lathraea squamaria, Paris quadrifolia, Viola reichenbachiana. Arányuk hasonló, mint a Szigetközben és a Mohácsi-szigeten (4. táblázat, 2. ábra B).

A mocsári növények (Phragmitetea s.l. incl. Magnocaricion) nem oly gyakoriak, mint a füzligetekben (Leucojo aestivi-Salicetum albae Kevey in Borhidi \& Kevey 1996): - K III: Iris pseudacorus, Phalaris arundinacea. - K II: Poa palustris - K I: Carex riparia, Lathyrus palustris, Phragmites australis, Solanum dulcamara, Stachys palustris. Arányuk a Csepel-sziget térségében és a Mohácsi-szigeten igen hasonló, míg a Szigetközben magasabb (4. táblázat, 2. ábra C).

Hasonló a helyzet a Galio-Urticetea s.l. (incl. Galio-Alliarion et Calystegion sepium) elemeknél is. Ezek aránya is igen hasonló a Csepel-sziget térségében és a Mohácsi-szigeten, a Szigetközben viszont magasabb: - K IV: Aristolochia clematitis. - K III: Alliaria petiolata, Chaerophyllum temulum. - K II: Aethusa cynapium, Calystegia sepium, Parietaria officinalis. K I: Barbarea stricta, Bryonia alba, Lamium maculatum, Myosoton aquaticum, Rumex obtusifolius (4. táblázat, 2. ábra D).

Szembetűnő, hogy a Quercetea pubescentis-petraeae elemek a Csepel-szigeten és térségében, az adventív (Adventiva) elemek pedig a Mohácsi-szigeten a leggyakoribbak a három tájegység közül (4. táblázat).

Végül a kontrollként használt csepel-szigeti tölgy-kőris-szil ligetek (Scillo vindobonensisUlmetum Kevey in Borhidi \& Kevey 1996) a karakterfajok tekintetében egyértelműen különbözik a Szigetköz, a Csepel-sziget környéke, valamint a Mohácsi-sziget fehérnyár-ligeteitől (Senecioni sarracenici-Populetum albae) (4. táblázat, 2. ábra A-D).

\section{Szociális magatartási típusok aránya}

A szociális magatartási típusok (BoRHIDI 1993, 1995) arányát tekintve a Csepel-sziget tölgykőris-szil ligetei (Scillo vindobonensis-Ulmetum) jól elkülönülnek a fehérnyár-ligetektől (Senecioni sarracenici-Populetum albae). Ezt bizonyítja a generalisták (G) magasabb, valamint a zavarástűrők (DT) alacsonyabb aránya. A fehérnyár-ligetek között inkább csak kisebb különbségek mutatkoznak. Megjegyzendő azonban, hogy közülük a Csepel-sziget és környékének fehérnyár-ligeteinél legnagyobb a specialisták (S) és a generalisták (G), továbbá legkisebb a zavarástứrők (DT) aránya (5. táblázat, 2. ábra E-F).

\section{Sokváltozós statisztikai elemzések eredményei}

A sokváltozós elemzések eredménye szerint a Csepel-sziget tölgy-kőris-szil ligeteinek (Scillo vindobonensis-Ulmetum) felvételei élesen különálló csoportot képeznek. Ezzel szemben a Szigetköz, de különösen a Csepel-sziget és a Mohácsi-sziget fehérnyár-ligetei (Senecioni sarracenici-Populetum albae) szorosan kapcsolódnak, továbbá két mohácsi-szigeti felvétel a csepelszigeti felvételek csoportjába került (3-4. ábra). 


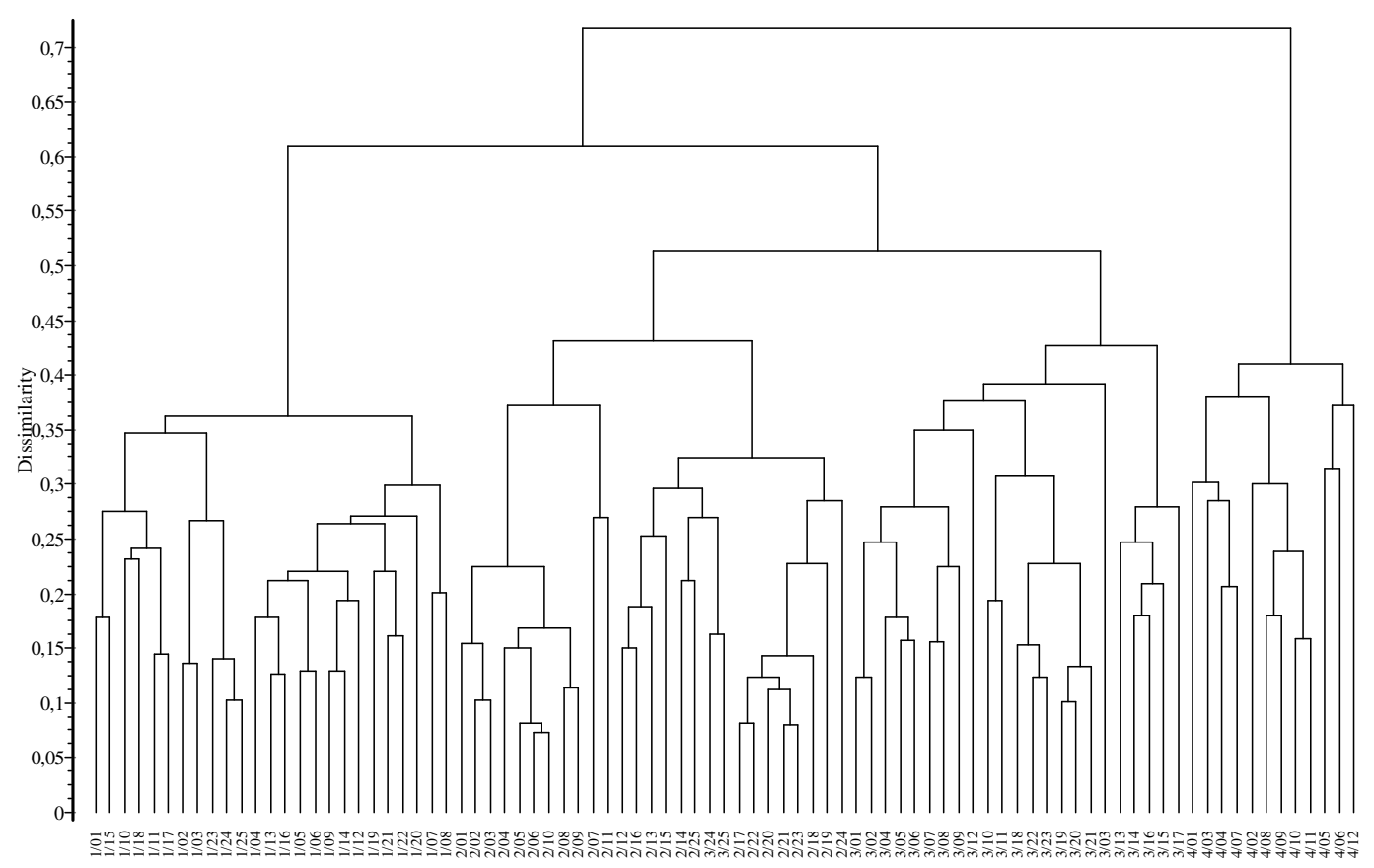

3. ábra Cönológiai felvételek bináris dendrogramja (hasonlósági index: Baroni-Urbani-Buser; osztályozó módszer: teljes lánc) Fig. 3 Binary dendrogram of the relevés

(similarity coefficient: Baroni-Urbani-Buser; clustering method: complete link)

1/1-25: Senecioni sarracenici-Populetum albae, Szigetköz (KeVEY 2008)

2/1-25: Senecioni sarracenici-Populetum albae, Csepel-sziget (KeVEY \& Huszár 1999 és Kevey 2008)

3/1-25: Senecioni sarracenici-Populetum albae, Mohácsi-sziget (KEVEY 2017)

4/1-12: Scillo vindobonensis-Ulmetum, Csepel-sziget (Kevey ined.)

Természetvédelmi eredmények

A vizsgált fehérnyár-ligetek a Natura 2000 hálózat részét képezik, azonban csupán a Budapest alatti „Háros-sziget” védelme tűnik megnyugtatónak. Másutt a tarvágások után a vágásterületeket sokfelé nemes nyárakkal (Populus $\times$ euramericana) telepítik be, $\mathrm{s}$ a természetszerủ fehérnyár-ligetek egyre kisebb foltokká zsugorodnak, amelyhez az idegenhonos Acer negundo és Fraxinus pennsylvanica spontán terjeszkedése is hozzájárul. A tarvágások után az erdőrészek igen nehezen regenerálódnak, inkább degradálódnak, út nyílik a tájidegen (adventív) fajok özönszerű terjeszkedése előtt. Ilyen növények a következők: - K IV: Acer negundo - K III: Impatiens parviflora, Vitis vulpina - K II: Celtis occidentalis, Morus alba, Robinia pseudo-acacia, Aster $\times$ salignus, Juglans regia - K I: Ailanthus altissima, Echinocystis lobata, Fraxinus pennsylvanica, Juglans nigra, Solidago gigantea, Amorpha fruticosa, Oxalis stricta, Populus $\times$ euramericana, Parthenocissus inserta, Stenactis annua (1. táblázat). A Csepel-sziget és környékének fehérnyár-ligeteiben e növények 8,68\% csoportrészesedéssel és 9,41\% csoporttömeggel fordulnak elő.

Fenti problémák ellenére a 25 felvételből nyolc értékes védett növényfaj került elő: - K V: Scilla vindobonensis - K IV: Leucojum aestivum - K III: Galanthus nivalis - K I: Crataegus nigra, Crataegus $\times$ degenii, Epipactis helleborine, Equisetum hyemale, Vitis sylvestris (1. táblázat). 
Közülük különösen a Duna mentén endemikus Crataegus nigra és hibridje a Crataegus $\times$ degenii érdemel említést. Dendrológiai értéket képviselnek egyes hatalmas termetű fák (Populus alba, Quercus robur, Ulmus laevis), amelyek törzsátmérője olykor a másfél-két métert is elérheti (főleg a Háros-szigeten), valamint egyes fává nőtt cserjék (Cornus sanguinea, Corylus avellana, Crataegus monogyna, Crataegus nigra) mintegy $40 \mathrm{~cm}$-es törzsátmérővel. E fehérnyár-ligetek megőrzése és termőhelyük rekonstrukciója természetvédelmünk egyik fontos feladat lehetne.

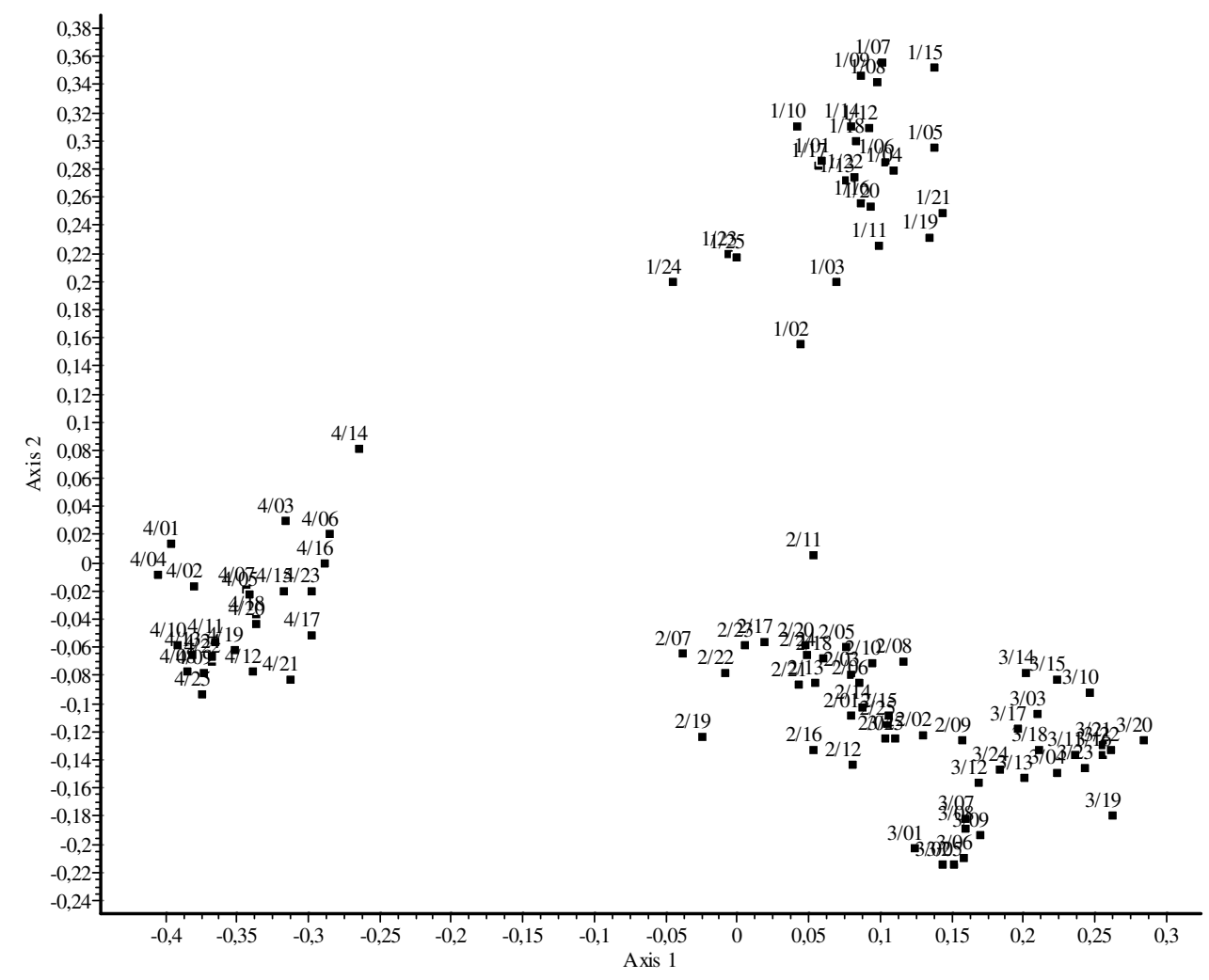

4. ábra Cönológiai felvételek bináris ordinációs diagramja

(hasonlósági index: Baroni-Urbani-Buser; ordinációs módszer: főkoordináta-analízis)

Fig. 4 Binary ordination diagram of the relevés

(similarity coefficient: Baroni-Urbani-Buser; ordination method: principal coordinates analysis)

\section{Megvitatás}

Az összehasonlító anyagként használt csepel-szigeti tölgy-kőris-szil liget (Scillo vindobonensis-Ulmetum) mind a hagyományos (4-5. táblázat, 2. ábra), mind pedig a sokváltozós (3-4. ábra) elemzés során egyértelműen elkülönült a Szigetköz, a Csepel-sziget és a Mohácsi-sziget fehérnyár-ligeteitől (Senecioni sarracenici-Populetum albae). Ez egyben azt is bizonyítja, hogy a Csepel-sziget fehérnyár-ligetei nem a tölgy-kőris-szil ligetek fehér nyáras konszociációját képezik.

Kutatásaim szerint az Alföld különböző tájegységein a fehérnyár-ligetek (Senecioni sarracenici-Populetum albae) (Kevey 1993, 2008, 2017, Kevey \& BARNA 2014, Kevey \& HuSzÁR 1999, KEVEY \& TóTH 2006, TóTH 1958) elkülöníthetők a mélyebb ártéri szintek füzligeteitől 
(Leucojo aestivi-Salicetum albae), valamint a magasabban fekvő tölgy-kőris-szil ligetektől (Pimpinello majoris-Ulmetum, Scillo vindobonensis-Ulmetum, Fraxino pannonicae-Ulmetum). Ezt az elkülönítést azonban több tényező is megnehezíti. Egyrészt ezen asszociációk között vannak átmeneti jellegű állományok is. Másrészt az ártereken tért hódító nemes nyár (Populus $\times$ euramericana agg.) ültetvények, valamint a spontán terjeszkedő tájidegen Acer negundo és Fraxinus pennsylvanica miatt a természetszerű puhafás ligeterdők kisebb állományokká zsugorodtak. Ilyen körülmények mellett ma már nagyon nehéz természetszerű - cönológiai felvételre alkalmas - fehérnyár-ligeteket találni. Fenti zavartság ellenére az állandósági osztályok eloszlása szerint az akcidens (K I) fajok mellett a konstans (K V) elemeknél jelentkezik egy második maximum (1. táblázat, 1. ábra), amely arra utal, hogy a vizsgált állományok még mindig természet-közeli állapotúak.

Ha összehasonlítjuk a Szigetköz, a Csepel-sziget és a Mohácsi-sziget fehérnyár-ligeteit, azt tapasztaljuk, hogy a karakterfajok aránya számos szüntaxon esetében (pl. Salicetea purpureae, Fagetalia, Galio-Urticetea stb.) hasonló (4. táblázat, 2. ábra A-D). Kisebb-nagyobb különbségek ugyan adódnak, de ezek nagyrészt a földrajzi távolsággal, a lokális vízrendezési viszonyokkal, az eltérő tájhasználattal (pl. erdőgazdálkodás) és a mintavétellel lehetnek öszszefüggésben. Hasonló összefüggéseket mutatnak a szociális magatartási típusok is (5. táblázat, 2. ábra E-F).

A sokváltozós elemzések (3-4. ábra) szerint is a Szigetköz, a Csepel-sziget és a Mohácsisziget fehérnyár-ligetei között elég nagy a hasonlóság, bár tájegységenkénti kisebb csoportosulások figyelhetők meg. Csupán a szigetközi felvételek mutatnak kissé nagyobb elkülönülést. E kisebb különbségek azonban nem indokolják a hazai fehérnyár-ligetek kisebb asszociációkra történő felbontását. Mind a hagyományos statisztikai (4-5. táblázat, 2. ábra), mind pedig a sokváltozós analízisek (3-4. ábra) eredményei azt mutatják, hogy a Csepel-sziget fehérnyár-ligete - a termőhelyi viszonyok, a fiziognómia és a fajkombináció alapján - olyan mértékben hasonlít a Szigetközből leírt Senecioni sarracenici-Populetum albae nevű asszociációhoz, hogy utóbbival azonosítható. A névadó Senecio sarracenicus ugyan e tájon nem került elő, ezért a társulás tudományos neve jelen esetben szimbolikusnak tekinthető. A társulás helye a növénytársulások rendszerében az alábbi módon vázolható:

\section{Divízió: Querco-Fagea Jakucs 1967}

Osztály: Salicetea purpureae Moor 1958

Rend: Salicetalia purpureae Moor 1958

Csoport: Salicion albae Soó 1930 em. Th. Müller \& Görs 1958

Alcsoport: Populenion nigro-albae Kevey 2008

Társulás: Senecioni sarracenici-Populetum albae Kevey in Borhidi \& Kevey 1996

A Csepel-sziget, a Szigetköz és a Mohácsi-sziget fehérnyár-ligeteinek (Senecioni sarraceniciPopuletum albae), valamint a Csepel-sziget tölgy-kőris-szil ligeteinek (Scillo vindobonensis-Ulmetum) összehasonlító elemzése" (4-5. táblázat, 2. ábra)ismét alátámasztja azt a nézetemet, hogy a fehérnyár-ligetek (Senecioni sarracenici-Populetum albae) nem tekinthetôk a tölgykőris-szil ligetek (Scillo vindobonensis-Ulmetum) fehérnyáras konszociációinak (KevEY 2016a, 2016b), hanem önálló asszociációt képeznek (vö. KEVEY 1993, 2008, 2016, KEVEY \& BARNA 2014).

\section{Köszönetnyilvánítás}

Köszönetem illeti Huszár Zsuzsanna egykori tanítványomat, aki a Háros-sziget fehérnyárligeteinek felmérésekor lelkesen segítette munkámat. 


\section{Irodalom}

BECKing R. W. (1957): The Zürich-Montpellier School of phytosociology. - Botanical Review 23: 411-488.

BoRHIDi A. (1993): A magyar flóra szociális magatartás típusai, természetességi és relatív ökológiai értékszámai. - Janus Pannonius Tudományegyetem, Pécs, 95 pp.

BoRHIDI A. (1995): Social behaviour types, the naturalness and relative ecological indicator values of the higher plants in the hungarian flora. - Acta Botanica Academiae Scientiarum Hungaricae 39: 97181.

Borhidi A. \& KeVEY B. (1996): An annotated checklist of the hungarian plant communities II. - In: Borhidi A. (ed.), Critical revision of the hungarian plant communities. Janus Pannonius University, Pécs, pp. 95-138.

Borhidi A., Kevey B. \& Lendvai G. (2012): Plant communities of Hungary. - Akadémiai Kiadó, Budapest, $544 \mathrm{pp}$.

BRAUN-BLANQUET J. (1964): Pflanzensoziologie (ed. 3.). - Springer Verlag, Wien-New York, 865 pp.

Horváth F., Dobolyi Z. K., MoRschHAuSER T., LőKÖs L., KARAS L. \& SZERdAHElYI T. (1995): Flóra adatbázis 1.2. - Vácrátót, 267 pp.

JAKUCS P. (1967): Gedanken zur höheren Systematik der europäischen Laubwälder. - Contribuţii Botanici Cluj 1967: 159-166.

Kevey B. (1993): A Szigetköz ligeterdeinek összehasonlító-cönológiai vizsgálata. - Kandidátusi értekezés (kézirat). Janus Pannonius Tudományegyetem Növénytani Tanszék, Pécs, 108 pp. + 32 fig. +70 tab.

KeveY B. (2008): Magyarország erdőtársulásai (Forest associations of Hungary). - Tilia 14: 1-488. + CDadatbázis (230 táblázat +244 ábra).

KEveY B. (2014): A hazai Mura-ártér fehérnyár-ligetei (Senecioni sarracenici-Populetum albae KEvEY in BoRHIDI et KEvey 1996). - Kaposvári Rippl-Rónai Múzeum Közleményei 3: 29-56.

KeveY B. (2016a): Puha- és keményfás ligeterdők kapcsolata a Szigetközben (The syntaxonomical relationship of softwood and hardwood gallery forests in the Szigetköz). - In: BARINA Z., BuczKó K., LőKÖs L., PAPP B., PIFKó D. \& SzURDOKI E. (szerk.), XI. Aktuális flóra- és vegetáció kutatás a Kárpátmedencében. Elöadások és poszterek összefoglalói, p. 24.

Kevey B. (2016b): Puha- és keményfás ligeterdők kapcsolata a Szigetközben. - Botanikai Közlemények 103(1): 45-115.

Kevey B. (2017): A Mohácsi-sziget fehérnyár-ligetei (Senecioni sarracenici-Populetum albae Kevey in BoRHIDI et KEVEY 1996). - Botanikai Közlemények 104(1): 131-146. + Elektronikus mellékletek (E1E5 táblázat).

KEvey B. \& BARNA Cs. (2014): A hazai Felső-Tisza-vidék fehérnyár-ligetei (Senecioni sarraceniciPopuletum albae KeveY in Borhid et KeveY 1996). - Botanikai Közlemények 101(1-2): 105-143.

Kevey B. \& BARNA Cs. (2018): A vasi Rába-völgy fehérnyár-ligetei (Senecioni sarracenici-Populetum albae Kevey in Borhidi \& Kevey 1996). - Kaposvári Rippl-Rónai Múzeum Közleményei 5: 19-42.

KEvey B. \& HiRmann A. (2002): „NS” számítógépes cönológiai programcsomag. - In: Aktuális flóra- és vegetációkutatások a Kárpát-medencében V. Pécs, 2002. március 8-10. (Összefoglalók), p. 74.

Kevey B. \& HuszÁR Zs. (1999): A Háros-sziget fehérnyár-ligetei (Senecioni sarracenici-Populetum albae Kevey in BoRHIDI et KeVEY 1996). - Természetvédelmi Közlemények 8: 37-48.

KeVEy B. \& TóTH V. (2006): A Baranyai-Dráva-sík fehérnyár-ligetei (Senecioni sarracenici-Populetum albae Kevey in Borhidi et KeveY 1996). - Natura Somogyiensis 9: 47-62.

KIRÁLY G. (szerk.) (2009): Új magyar füvészkönyv. Magyarország hajtásos növényei. Határozókulcsok. Aggteleki Nemzeti Park Igazgatóság, Jósvafő, 616 pp.

Moor M. (1958): Die Pflanzengesellschaften schweizerischer Flußauen. - Mitteilungen der Schweizerischen Anstalt für das Forstliche Versuchswesen 34: 221-360.

Mucina L., GrabherR G. \& WAllnöfer S. (1993): Die Pflanzengesellschaften Österreichs III. Wälder und Gebüsche. - Gustav Fischer, Jena-Stuttgart-New York, 353 pp.

MÜLLER Th. \& GöRS S. (1958): Zur Kenntnis einiger Auenwaldgesellschaften im württembergischen Oberland. - Beiträge zur naturkundlichen Forschung in Südwestdeutschland 17: 88-165.

OBERDORFER E. (1992): Süddeutsche Pflanzengesellschaften IV. A. Textband. - Gustav Fischer Verlag, Jena - Stuttgart - New York, 282 pp.

PoDANi J. (2001): SYN-TAX 2000 Computer Programs for Data Analysis in Ecologi and Systematics. Scientia, Budapest, 53 pp. 
Simon T. (1957): Die Wälder des nördlichen Alföld. - In: ZóLYomi B. (ed.), Die Vegetation ungarischer Landschaften 1. Akadémiai Kiadó, Budapest, 172 pp. + 22 tab. + 2 chart.

Soó R. (1958): Die Wälder des Alföld. - Acta Botanica Academiae Scientiarum Hungaricae 4: 351-381.

Soó R. (1964, 1966, 1968, 1970, 1973, 1980): A magyar flóra és vegetáció rendszertani-növényföldrajzi kézikönyve I-VI. - Akadémiai kiadó, Budapest.

Szirmai O., Tuba Z., Nagy J., Cserhalmi D., Czóbel Sz., Gál B., Szerdahelyi T. \& Marschall Z. (2008): A Bodrogköz növénytársulásainak áttekintése. - In: TuBA Z. (szerk.), Bodrogköz. A magyarországi Bodrogköz tájmonográfiája. Lorántffy Zsuzsanna Szellemében Alapítvány, Gödöllő-Sárospatak, pp. 523-584.

TóTH I. (1958): Az Alsó-Dunaártér erdőgazdálkodása, a termőhely- és az erdőtípusok összefüggése. Erdészeti Kutatások 1958 (1-2): 77-160.

Beérkezett / received: 2020. 01.28. • Elfogadva / accepted: 2020. 02. 27.

\section{Rövidítések}

A1: felső lombkoronaszint; A2: alsó lombkoronaszint; Adv: Adventiva; Agi: Alnenion glutinosae-incanae; Ai: Alnion incanae; Alo: Alopecurion pratensis; AQ: Aceri tatariciQuercion; AR: Agropyro-Rumicion crispi; Ara: Arrhenatheretalia; Arc: Arction lappae; Ata: Alnetalia glutinosae; B1: cserjeszint; B2: újulat; Bia: Bidentetalia; Bon: Bidention tripartiti; C: gyepszint; Cgr: Caricenion gracilis; Che: Chenopodietea; ChS: Chenopodio-Scleranthea; $\mathrm{Cn}$ : Calystegion sepium; Cp: Carpinenion betuli; CyF: Cynodonto-Festucenion; Des: Deschampsion caespitosae; Epa: Epilobietalia; Epn: Epilobion angustifolii; F: Fagetalia sylvaticae; FBt: Festuco-Brometea; FiC: Filipendulo-Cirsion oleracei; FPe: FestucoPuccinellietea; FPi: Festuco-Puccinellietalia; Fru: Festucion rupicolae; GA: Galio-Alliarion; incl.: inclusive (beleértve); I: Indifferens; ined.: ineditum (kiadatlan közlés); Mag: Magnocaricion; Moa: Molinietalia coeruleae; MoA: Molinio-Arrhenatherea; Moa: MolinioJuncetea; Pla: Plantaginetalia majoris; Pna: Populenion nigro-albae; Prf: Prunion fruticosae; Pru: Prunetalia spinosae; Pte: Phragmitetea; QFt: Querco-Fagetea; Qpp: Quercetea pubescentis-petraeae; S: summa (összeg); Sal: Salicion albae; SaS: Sambuco-Salicion capreae; SCn: Scheuchzerio-Caricetalia nigrae; Sea: Secalietea; Spu: Salicetalia purpureae; TA: Tilio platyphyllae-Acerenion pseudoplatani; Ulm: Ulmenion. 
KEVEY (2020): A Csepel-sziget fehérnyár-ligetei

1. táblázat Senecioni sarracenici-Populetum albae

Table 1 Senecioni sarracenici-Populetum albae

\begin{tabular}{|c|c|c|c|c|c|c|c|c|c|c|c|c|c|c|c|c|c|c|c|c|c|c|c|c|c|c|c|c|c|c|}
\hline & & 1 & 2 & 3 & 4 & 5 & 6 & 7 & 8 & 9 & $\begin{array}{l}\mathbf{1} \\
\mathbf{0}\end{array}$ & $\begin{array}{l}1 \\
1\end{array}$ & $\begin{array}{l}1 \\
2 \\
\end{array}$ & $\begin{array}{l}1 \\
3 \\
\end{array}$ & $\begin{array}{l}1 \\
4 \\
\end{array}$ & & & & & & & & & & $\begin{array}{ll}2 & 2 \\
3 & 4 \\
\end{array}$ & & $\begin{array}{r}2 \\
5 \\
\end{array}$ & A-D & $\mathbf{K}$ & K\% \\
\hline \multicolumn{31}{|l|}{$\begin{array}{l}\text { 1. Querco-Fagea } \\
\text { 1.1. Salicetea purpureae } \\
\text { 1.1.1. Salicetalia purpureae }\end{array}$} \\
\hline \multirow[t]{5}{*}{ Populus nigra } & $\mathrm{A} 1$ & 2 & & & 2 & 1 & 2 & 2 & - & 1 & - & 1 & 1 & - & - & 3 & 1 & 3 & 2 & 2 & 21 & 11 & $1+$ & + & 2 & + & - & +-3 & IV & 80 \\
\hline & A2 & - & + & & - & - & - & - & - & - & - & - & - & - & - & - & - & - & - & 1 & $1-$ & - & - & . & - & - & - & +-1 & I & 8 \\
\hline & B1 & - & - & - & - & - & - & - & - & - & - & - & - & - & - & - & - & + & - & - & - & 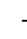 & 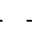 & . & - & - & - & + & I & 4 \\
\hline & B2 & - & - & - & - & - & - & - & - & - & - & - & - & - & - & - & - & + & - - & - & . & 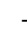 & - & . & + & - & + & + & I & 12 \\
\hline & S & 2 & 2 & 2 & 2 & 1 & 2 & 2 & - & 1 & - & 1 & 1 & - & - & 3 & 1 & 3 & 2 & 2 & 21 & 1 & 1 & + & 2 & + & + & +-3 & $\mathrm{~V}$ & 84 \\
\hline \multicolumn{31}{|l|}{ 1.1.1.1. Salicion albae } \\
\hline Leucojum aestivum (Des) & $\mathrm{C}$ & + & + & + & + & + & + & - & 1 & 3 & + & - & - & - & - & - & - & + & + & + & + & + & + & + & + & - & + & +-3 & IV & 64 \\
\hline \multirow[t]{5}{*}{ Humulus lupulus (Cn, Ata, Ai) } & B1 & + & + & 1 & - & + & + & + & - & - & - & + & + & + & + & - & - & - & - & - & - & - & 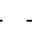 & . & - & - & + & +-1 & III & 44 \\
\hline & B2 & - & - & - & - & - & - & - & - & - & - & - & - & - & + & - & - & - & - & - & - & - & 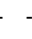 & . & - & - & - & + & I & 4 \\
\hline & C & + & + & + & - & + & + & + & - & - & + & + & + & + & + & + & + & - - & - & + & + & - & - & . & - & - & + & + & III & 60 \\
\hline & $S$ & + & + & 1 & - & + & + & + & - & - & + & + & + & + & 1 & + & + & - - & - & + & + & - & - & . & - & - & + & +-1 & III & 60 \\
\hline & & - & - & & - & - & + & + & - & - & - & - & - & + & + & + & + & + & + & + & ++ & + & + & + & + & - & + & + & III & 56 \\
\hline Carduus crispus (Cn) & $\mathrm{C}$ & - & - & - & - & - & - & - & - & - & - & - & - & - & + & - & - & - & - & 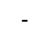 & - & - & 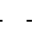 & . & - & + & - & + & I & 8 \\
\hline Crataegus nigra (Ulm) & B1 & - & - & - & - & - & - & - & - & - & - & - & - & - & - & - & - & - & + & - & . & . & - & . & - & - & - & + & I & 4 \\
\hline Crataegus $\times$ degeni $(\mathrm{Ulm})$ & B1 & - & - & - & - & - & - & - & - & - & - & - & - & - & - & - & - & - & + & - & 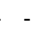 & . & 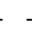 & . & - & - & - & + & I & 4 \\
\hline Salix alba $(\mathrm{Ai}, \mathrm{Cn})$ & $\mathrm{A} 1$ & - & - & - & - & - & - & - & - & - & - & - & - & - & - & - & - & - & - & - & . & - & 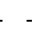 & - & - & - & + & + & I & 4 \\
\hline \multicolumn{31}{|l|}{ 1.2. Querco-Fagetea } \\
\hline \multirow[t]{4}{*}{ Cornus sanguinea (Qpp) } & A2 & - & - & - & - & - & - & - & - & - & - & - & - & - & - & - & - & - & - & - & - & . & 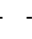 & - & - & + & - & + & I & 4 \\
\hline & B1 & 4 & 4 & 4 & 3 & 3 & 4 & 3 & 4 & 3 & 3 & 2 & 1 & 1 & 2 & 3 & 2 & + & 3 & 2 & 23 & 32 & 2 & + & 1 & 1 & 2 & +-4 & $\mathrm{~V}$ & 100 \\
\hline & B2 & 1 & 1 & + & 1 & 1 & 1 & 1 & 1 & 1 & 1 & + & + & + & + & 1 & 2 & + & + & + & ++ & + & ++ & + & + & + & + & +-2 & $\mathrm{~V}$ & 100 \\
\hline & S & 4 & 4 & 4 & 3 & 3 & 4 & 3 & 4 & 3 & 3 & 2 & 1 & 1 & 2 & 3 & 3 & + & -3 & 2 & 23 & 32 & $2+$ & + & 1 & 1 & 2 & +-4 & $\mathrm{~V}$ & 100 \\
\hline Ranunculus ficaria & $\mathrm{C}$ & + & + & + & + & 3 & 3 & 1 & + & + & 2 & 3 & 3 & 2 & 2 & 2 & 3 & 4 & +2 & 4 & 43 & 33 & 3 & 4 & 4 & 3 & 5 & +-5 & $\mathrm{~V}$ & 100 \\
\hline \multirow[t]{5}{*}{ Ulmus minor (Ai, Ulm, Qpp) } & A1 & - & - & - & - & - & - & - & - & - & - & - & - & - & - & - & - & - & - & 1 & $1-$ & - & - & - & - & + & - & +-1 & I & 8 \\
\hline & A2 & 2 & 2 & 1 & 1 & + & 2 & 2 & 2 & 2 & + & 1 & 2 & 1 & - & + & - & 2 & 2 & 2 & $2+$ & + & +1 & 1 & 1 & 2 & 1 & +-2 & V & 92 \\
\hline & B1 & 1 & 1 & & + & + & 1 & 1 & - & 1 & 1 & + & 2 & 2 & - & + & + & 2 & 21 & 1 & $1+$ & + & 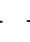 & + & +2 & 2 & + & +-2 & $\mathrm{~V}$ & 88 \\
\hline & B2 & 1 & 2 & + & + & - & + & - & + & - & + & + & + & 1 & + & + & - & 1 & $1+$ & -1 & $1-$ & - & 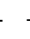 & + & + & + & + & +-2 & IV & 76 \\
\hline & $S$ & 2 & 3 & 2 & 1 & + & 2 & 2 & 2 & 2 & 1 & 1 & 3 & 2 & + & 1 & + & 3 & 32 & 2 & $2+$ & + & +1 & 1 & 1 & 3 & 1 & +-3 & $\mathrm{~V}$ & 100 \\
\hline \multirow[t]{3}{*}{ Euonymus europaeus (Qpp) } & B1 & + & + & + & 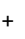 & + & + & + & - & - & + & + & + & + & + & + & - & 1 & $1+$ & -1 & $1+$ & + & - & - & + & + & + & +-1 & IV & 80 \\
\hline & B2 & + & + & & 1 & + & + & + & + & - & + & + & + & 1 & + & 1 & + & + & + & -1 & $1+$ & & + & + & + & + & + & +-1 & $\mathrm{~V}$ & 96 \\
\hline & s & + & + & 1 & 1 & + & + & + & + & - & + & + & + & 1 & + & 1 & + & 1 & $1+$ & -2 & $2+$ & + & + & + & + & + & + & +-2 & $\mathrm{~V}$ & 96 \\
\hline \multirow[t]{4}{*}{ Quercus robur (Ai, Cp, Qpp) } & A1 & - & - & 1 & - & 1 & - & - & + & 1 & - & - & 1 & 1 & 1 & - & - & 2 & 2 & 1 & 12 & 21 & 12 & 2 & 1 & 1 & 1 & +-2 & IV & 64 \\
\hline & $\mathrm{A} 2$ & 1 & - & & - & - & - & - & - & - & - & - & - & - & - & - & - & - & + & -+ & +- & - - & - & - & - & - & - & +-1 & I & 12 \\
\hline & B2 & + & + & & + & + & + & + & + & + & + & - & + & + & + & + & + & + & - & + & +- & - & - & + & + & + & - & + & IV & 80 \\
\hline & s & 1 & + & 1 & + & 1 & + & + & + & 1 & + & - & 1 & 1 & 1 & + & + & 2 & 2 & 1 & 12 & 21 & 12 & 2 & 1 & 1 & 1 & +-2 & $\mathrm{~V}$ & 96 \\
\hline Polygonatum latifolium (Qpp) & $\mathrm{C}$ & + & + & + & 1 & 1 & + & 3 & + & + & + & - & 2 & 2 & + & - & + & 1 & + & -1 & $1+$ & + & +1 & 1 & 1 & + & + & +-3 & V & 92 \\
\hline \multirow[t]{5}{*}{ Acer campestre (Qpp) } & A1 & - & - & - & - & 2 & - & - & - & - & - & - & - & - & - & - & - & 1 & 2 & 2 & $2-$ & - & -1 & 1 & + & - & - & +-2 & II & 24 \\
\hline & A2 & - & + & + & - & 1 & - & 3 & - & - & - & - & - & - & 1 & - & 1 & 2 & 2 & 3 & 31 & 1 & +2 & 2 & 2 & - & - & +-3 & III & 52 \\
\hline & B1 & + & + & + & + & + & + & 1 & - & - & + & - & - & 1 & 2 & 1 & 1 & 2 & + & -2 & $2+$ & + & 2 & 2 & 1 & - & 1 & +-2 & IV & 76 \\
\hline & B2 & + & + & + & + & + & - & - & - & - & + & - & + & + & + & + & + & + & + & -+ & + & + & - & + & + & - & + & + & IV & 72 \\
\hline & S & + & 1 & & + & 2 & + & 3 & - & - & + & - & + & 1 & 2 & 1 & 2 & 3 & 3 & 34 & 41 & 1 & +3 & 3 & 2 & - & 1 & +-4 & $\mathrm{~V}$ & 84 \\
\hline Convallaria majalis (Qpp) & $\mathrm{C}$ & 1 & + & + & 3 & 2 & 1 & + & 2 & + & 2 & - & - & + & - & - & + & 1 & 1 & 2 & $2+$ & + & +1 & 1 & 2 & - & - & +-3 & IV & 76 \\
\hline Crataegus monogyna (Qpp) & A2 & + & 1 & & - & - & - & - & - & - & - & - & - & - & - & - & - & - & - & + & +- & - & - & - & - & - & - & +-1 & I & 16 \\
\hline & B1 & + & 1 & & + & 1 & + & 1 & + & - & 1 & + & - & + & - & + & - & 1 & + & -1 & $1+$ & + & - & + & + & - & - & +-1 & IV & 72 \\
\hline & B2 & + & + & & + & + & + & - & - & - & - & - & - & - & - & + & - & + & + & + & + & 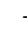 & + & + & - & - & - & + & III & 44 \\
\hline & $\mathrm{S}$ & 1 & 2 & + & + & 1 & + & 1 & + & - & 1 & + & - & + & - & + & - & 1 & + & +1 & $1+$ & + & + & + & + & - & - & +-2 & IV & 76 \\
\hline
\end{tabular}


Kitaibelia 25(1): 57-78.

\begin{tabular}{|c|c|c|c|c|c|c|c|c|c|c|c|c|c|c|c|c|c|c|c|c|c|c|c|c|c|c|c|c|c|c|}
\hline & & 1 & 2 & 3 & 4 & 5 & 6 & 7 & 8 & 9 & $\begin{array}{l}\mathbf{1} \\
\mathbf{0} \\
\end{array}$ & $\begin{array}{l}1 \\
1 \\
\end{array}$ & $\begin{array}{l}1 \\
2 \\
\end{array}$ & $\begin{array}{l}1 \\
3 \\
\end{array}$ & $\begin{array}{l}1 \\
4 \\
\end{array}$ & $\begin{array}{l}1 \\
5\end{array}$ & $\begin{array}{l}1 \\
6\end{array}$ & $\begin{array}{l}1 \\
7\end{array}$ & $\begin{array}{l}1 \\
8 \\
\end{array}$ & $\begin{array}{l}1 \\
9 \\
\end{array}$ & $\begin{array}{l}2 \\
0\end{array}$ & $\begin{array}{l}2 \\
1 \\
\end{array}$ & & 2 & & & & A-D & $\mathbf{K}$ & K\% \\
\hline Viola suavis s.l. (Qpp) & $\mathrm{C}$ & + & - & - & - & - & - & + & - & - & - & + & 1 & 1 & 2 & + & + & 1 & + & 2 & 1 & 1 & 2 & 2 & 1 & $1+$ & & +-2 & IV & 68 \\
\hline Veronica sublobata & $\mathrm{C}$ & - & - & - & - & - & - & - & - & - & - & + & 1 & 1 & 1 & 2 & 1 & + & + & + & + & + & + & + & + & ++ & & +-2 & III & 60 \\
\hline Brachypodium sylvaticum (Qpp) & $\mathrm{C}$ & - & - & - & - & - & - & + & - & - & - & - & + & + & + & + & + & + & + & 1 & + & - & + & 1 & $1+$ & ++ & & +-1 & III & 56 \\
\hline Scrophularia nodosa (GA, Epa) & $\mathrm{C}$ & - & - & - & - & - & - & - & - & - & - & + & + & + & - & + & + & + & + & + & - & + & + & + & + & ++ & & + & III & 52 \\
\hline Geranium robertianum (Еpa) & $\mathrm{C}$ & - & - & - & - & - & - & - & - & - & - & - & + & + & + & - & - & + & + & 1 & + & + & + & 1 & + & ++ & & +-1 & III & 48 \\
\hline Geum urbanum (Epa, Cp, Qpp) & C & - & - & - & - & - & - & - & - & - & - & - & + & + & + & - & + & . 1 & + & 1 & - & + & + & + & + & + & & +-1 & III & 48 \\
\hline \multirow[t]{4}{*}{ Corylus avellana (Qpp) } & A2 & - & - & - & - & - & - & - & - & - & - & - & - & - & - & - & - & + & - & 1 & - & + & - & + & 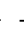 & - & & +-1 & I & 16 \\
\hline & B1 & - & - & - & - & - & - & - & - & - & - & + & - & - & + & - & - & + & - & 2 & + & - & + & + & - & - & & +-2 & II & 28 \\
\hline & B2 & - & - & - & - & - & - & + & - & - & - & - & - & - & + & - & - & + & - & - & - & + & - & + & - & + & & + & II & 24 \\
\hline & $S$ & - & - & - & - & - & - & + & - & - & - & + & - & - & + & - & - & 1 & - & 2 & + & + & + & - 1 & . & + & & +-2 & II & 40 \\
\hline Lapsana communis (Qpp, GA, Epa) & $\mathrm{C}$ & - & - & - & - & - & - & - & - & - & - & + & + & + & + & + & + & - & - & + & + & - & - & + & - & + & & + & II & 40 \\
\hline Carex divulsa & C & + & + & - & + & - & + & - & + & + & + & + & - & - & - & + & - & - & - & - & - & - & - & - & 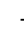 & - & & + & II & 36 \\
\hline \multirow[t]{3}{*}{ Ligustrum vulgare (Cp, Qpp) } & B1 & - & - & - & + & - & - & + & - & - & - & - & - & - & - & - & - & - & - & - & + & - & - & + & . & - & & + & I & 16 \\
\hline & B2 & - & - & - & - & - & - & + & - & - & - & - & - & + & - & - & - & + & - & - & - & - & + & + & 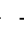 & - & & + & I & 20 \\
\hline & $S$ & - & - & - & + & - & - & + & - & - & - & - & - & + & - & - & - & + & - & - & + & - & + & + & 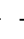 & - & & + & II & 28 \\
\hline Fallopia dumetorum (Qpp, GA) & $\mathrm{C}$ & - & - & - & - & - & - & - & - & - & - & + & - & + & + & - & - & - & - & + & - & - & - & - & 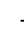 & - & & + & I & 16 \\
\hline \multirow[t]{3}{*}{ Rhamnus catharticus (Qpp, Pru) } & B1 & - & - & - & - & - & - & - & - & - & - & + & - & - & - & - & - & - & - & + & - & - & - & - & - & - & & + & I & 8 \\
\hline & B2 & - & - & + & - & - & - & - & - & - & - & + & - & - & - & - & - & - & - & + & - & - & - & - & 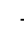 & + & & + & I & 16 \\
\hline & S & - & - & + & - & - & - & - & - & - & - & + & - & - & - & - & - & - & - & + & - & - & - & - & - & + & & + & I & 16 \\
\hline Carex spicata (Qpp, Epa) & C & - & - & - & - & - & - & - & - & - & - & - & - & - & - & - & - & - & - & - & - & + & + & + & 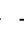 & - & & + & I & 12 \\
\hline \multirow[t]{3}{*}{ Fraxinus excelsior (Qpp, TA) } & B1 & - & - & - & - & - & - & - & - & - & - & - & - & - & - & - & - & + & - & - & - & - & - & + & - & - & & + & I & 8 \\
\hline & B2 & - & - & - & - & - & - & - & - & - & - & - & - & - & - & - & - & + & - & - & - & + & - & + & . & - & & + & I & 12 \\
\hline & S & - & - & - & - & - & - & - & - & - & - & - & - & - & - & - & - & + & - & - & - & + & - & + & - & - & & + & I & 12 \\
\hline Poa nemoralis (Qpp) & $\mathrm{C}$ & - & - & - & - & - & - & - & - & - & - & - & + & - & + & - & - & - & - & + & - & - & - & - & 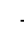 & - & & + & I & 12 \\
\hline Clematis vitalba (Qpp) & B2 & - & - & - & - & - & - & - & - & - & - & - & - & - & + & - & - & - & - & - & - & - & - & - & - & - & & + & I & 4 \\
\hline $\begin{array}{l}\text { Dactylis polygama (Qpp, Cp) } \\
\text { 1.2.1. Fagetalia sylvaticae }\end{array}$ & C & - & - & - & - & - & - & - & - & - & - & - & - & - & - & - & + & - - & - & - & - & - & - & - & - & - & & + & I & 4 \\
\hline Scilla vindobonensis $(\mathrm{Ai}, \mathrm{Cp})$ & $\mathrm{C}$ & + & + & + & + & 1 & 2 & 3 & 2 & + & + & 3 & 2 & 2 & 2 & 1 & 2 & 1 & 1 & 2 & 2 & 2 & 2 & 2 & . & 1 & & +-3 & $\mathrm{~V}$ & 100 \\
\hline Circaea lutetiana (Ai) & C & + & + & 1 & + & + & + & - & - & - & + & - & + & - & + & - & + & 1 & 2 & + & 1 & 2 & 2 & 1 & - & + & & +-2 & IV & 76 \\
\hline Galeopsis speciosa (Epn, Ai) & C & + & + & + & 1 & + & + & - & + & + & + & + & - & - & - & - & - & - & - & + & - & + & + & + & 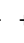 & + & & +-1 & IV & 64 \\
\hline Galanthus nivalis & $\mathrm{C}$ & - & - & - & + & 2 & 2 & + & - & - & 1 & - & - & - & - & - & - & - & + & + & + & 1 & 1 & 1 & 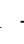 & - & & +-2 & III & 44 \\
\hline Moehringia trinervia & $\mathrm{C}$ & - & - & - & - & - & - & - & - & - & - & - & + & - & - & - & - & + & + & + & + & + & - & + & - & + & & + & II & 36 \\
\hline \multirow[t]{3}{*}{ Hedera helix } & B1 & - & - & - & - & - & - & - & - & - & - & + & - & - & - & - & + & - & - & - & - & - & - & - & - & - & & + & I & 8 \\
\hline & B2 & - & - & - & + & - & - & + & - & - & - & 1 & - & - & + & + & + & - - & - & - & - & - & - & - & 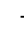 & + & & +-1 & II & 28 \\
\hline & S & - & - & - & + & - & - & + & - & - & - & 1 & - & - & + & + & + & - - & - & - & - & - & - & - & - & + & & +-1 & II & 28 \\
\hline Carex sylvatica & C & - & - & - & - & - & - & - & - & - & - & - & - & - & - & - & - & + & + & + & - & + & + & 1 & 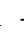 & - & & +-1 & II & 24 \\
\hline Stachys sylvatica (Epa) & $\mathrm{C}$ & - & - & - & - & - & - & - & - & - & - & - & - & - & - & - & - & + & + & + & + & - & + & + & - & - & & + & II & 24 \\
\hline \multirow[t]{3}{*}{ Acer platanoides $(\mathrm{TA})$} & A2 & - & - & - & - & - & - & - & - & - & - & - & - & + & - & - & - & - & - & - & - & - & - & - & - & - & & + & I & 4 \\
\hline & B1 & - & - & - & - & - & - & + & - & - & - & - & - & - & - & - & - & - & - & - & - & - & - & - & 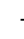 & - & & + & I & 4 \\
\hline & s & - & - & - & - & - & - & + & - & - & - & - & - & + & - & - & - & - & - & - & - & - & - & - & - & - & & + & I & 8 \\
\hline Acer pseudo-platanus (TA) & B1 & - & - & - & - & - & - & - & - & - & - & - & - & - & - & - & - & - & - & - & - & + & - & + & - & - & & + & I & 8 \\
\hline Epipactis helleborine agg. & $\mathrm{C}$ & - & - & - & - & - & - & - & - & - & - & + & - & - & - & + & - & - & - & - & - & - & - & - & - & - & & + & I & 8 \\
\hline Gagea lutea $(\mathrm{Ai}, \mathrm{Cp})$ & $\mathrm{C}$ & - & - & - & - & - & - & - & - & - & - & - & - & - & - & - & - & - & - & - & - & - & + & + & . & - & & + & I & 8 \\
\hline Paris quadrifolia (Ata, Ai) & $\mathrm{C}$ & - & - & - & - & - & - & - & - & - & - & - & - & - & - & - & - & + & + & - & - & - & - & - & 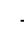 & - & & + & I & 8 \\
\hline Anemone ranunculoides & $\mathrm{C}$ & - & - & - & - & - & - & - & - & - & - & - & - & - & - & - & - & - & - & + & - & - & - & - & - & - & & + & I & 4 \\
\hline Cerasus avium (Cp) & B1 & - & - & - & - & - & - & - & - & - & - & + & - & - & - & - & - & - & - & - & - & - & - & - & - & - & & + & I & 4 \\
\hline Lathraea squamaria (Cp) & $\mathrm{C}$ & - & - & - & - & - & - & - & - & - & - & - & - & - & - & - & - & - & - & + & - & - & - & - & - & 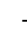 & & + & I & 4 \\
\hline Viola reichenbachiana & $\mathrm{C}$ & - & - & - & - & - & - & - & - & - & - & - & - & - & - & - & - & - & - & - & - & - & - & - & 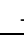 & - & & + & I & 4 \\
\hline
\end{tabular}


KEVEY (2020): A Csepel-sziget fehérnyár-ligetei

\begin{tabular}{|c|c|c|c|c|c|c|c|c|c|c|c|c|c|c|c|c|c|c|c|c|c|c|c|c|c|c|c|c|c|c|}
\hline & & 1 & 2 & 3 & 4 & 5 & 6 & 7 & 8 & 9 & $\begin{array}{l}\mathbf{1} \\
\mathbf{0} \\
\end{array}$ & $\begin{array}{l}1 \\
1 \\
\end{array}$ & $\begin{array}{l}1 \\
2 \\
\end{array}$ & $\begin{array}{l}1 \\
\mathbf{3} \\
\end{array}$ & $\begin{array}{l}1 \\
4 \\
\end{array}$ & $\begin{array}{l}1 \\
5 \\
\end{array}$ & $\begin{array}{l}1 \\
6 \\
\end{array}$ & & & & & & & & $\begin{array}{ll}2 & 2 \\
3 & 4 \\
\end{array}$ & & \begin{tabular}{l|l}
2 & \\
5 & \\
\end{tabular} & A-D & $\mathbf{K}$ & $\mathbf{K} \%$ \\
\hline \multicolumn{31}{|l|}{ 1.2.1.1. Alnion incanae } \\
\hline \multirow[t]{5}{*}{ Populus alba (Sal, AQ) } & A1 & 3 & 3 & 3 & 3 & 3 & 3 & 3 & 4 & 3 & 4 & 4 & 3 & 4 & 4 & 3 & 4 & 3 & 3 & 33 & 34 & 44 & 4 & 4 & 3 & 4 & 3 & $3-4$ & V & 100 \\
\hline & A2 & 2 & 2 & 2 & 1 & - & - & - & 1 & 1 & - & 1 & 1 & - & 2 & 2 & 2 & - & - & -1 & 12 & 21 & 1 & 2 & - & 1 & 2 & $1-2$ & IV & 68 \\
\hline & B1 & + & - & - & - & - & - & - & - & - & - & 1 & + & - & - & - & - & + & - & - & - & - & - & 1 & + & - & - & +-1 & II & 24 \\
\hline & B2 & + & + & + & + & + & + & + & + & + & + & 1 & + & + & + & + & 1 & + & + & + & ++ & ++ & + & + & + & + & + & +-1 & $\mathrm{~V}$ & 100 \\
\hline & S & 4 & 4 & 4 & 3 & 3 & 3 & 3 & 4 & 3 & 4 & 4 & 3 & 4 & 5 & 4 & 5 & 3 & 3 & 33 & 35 & 54 & 4 & 5 & 3 & 4 & 4 & $3-5$ & $\mathrm{~V}$ & 100 \\
\hline \multirow[t]{5}{*}{ Ulmus laevis (Sal, Ulm) } & A1 & 1 & - & + & 2 & 2 & 1 & + & + & + & - & 1 & 1 & - & - & + & - & + & + & +- & -+ & +- & - & - & 2 & + & 1 & +-2 & IV & 68 \\
\hline & A2 & + & 1 & 2 & 2 & 2 & 2 & - & 2 & 2 & 2 & 2 & 1 & 1 & 1 & + & 1 & 2 & $2+$ & ++ & +1 & 12 & 2 & 1 & 2 & 1 & - & +-2 & $\mathrm{~V}$ & 92 \\
\hline & B1 & + & - & + & 1 & + & + & - & - & - & 1 & + & + & - & + & - & - & + & - & - & - & -+ & + & + & 1 & 1 & - & +-1 & III & 56 \\
\hline & B2 & + & - & - & + & - & - & - & + & - & + & - & - & - & + & - & + & + & - & - & + & ++ & + & - & + & + & - & + & III & 44 \\
\hline & $S$ & 1 & 1 & 2 & 3 & 3 & 2 & + & 2 & 2 & 2 & 2 & 2 & 1 & 1 & + & 1 & 2 & $2+$ & + & +1 & 12 & 2 & 1 & 3 & 2 & 1 & +-3 & $\mathrm{~V}$ & 100 \\
\hline \multirow[t]{3}{*}{ Viburnum opulus (Ata) } & B1 & + & + & + & + & - & - & - & 1 & - & + & - & - & - & + & + & + & + & + & + & + & +- & - & + & + & - & - & +-1 & III & 56 \\
\hline & B2 & + & + & + & - & + & + & - & + & + & - & - & + & - & + & + & + & + & + & + & + & ++ & + & + & + & + & + & + & IV & 76 \\
\hline & S & + & + & + & + & + & + & - & 1 & + & + & - & + & - & + & + & + & + & + & - & -+ & ++ & + & + & + & + & + & +-1 & $\mathrm{~V}$ & 84 \\
\hline Carex remota & $\mathrm{C}$ & - & - & - & - & - & - & - & - & - & - & - & + & + & + & + & + & + & + & ++ & ++ & ++ & + & + & + & - & + & + & III & 52 \\
\hline Rumex sanguineus (Epa, Pna) & $\mathrm{C}$ & - & - & - & - & - & - & - & + & + & + & - & - & + & + & - & - & + & + & ++ & ++ & ++ & + & + & + & + & - & + & III & 52 \\
\hline Festuca gigantea (Cn, Epa) & $\mathrm{C}$ & - & - & - & - & - & - & - & - & - & - & - & + & + & - & - & + & + & + & ++ & ++ & ++ & + & + & + & - & + & + & III & 44 \\
\hline \multirow[t]{5}{*}{ Fraxinus angustifolia ssp. danubialis (Ata) } & A1 & - & - & - & - & - & 1 & - & - & 1 & - & - & - & 1 & - & - & - & - & - & - & 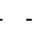 & - & - & - & - & - & 2 & $1-2$ & I & 16 \\
\hline & A2 & - & - & + & - & + & 1 & - & - & 1 & - & - & - & - & - & - & - & - & - & - & 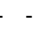 & $-\quad-$ & - & - & - & - & 2 & +-2 & I & 20 \\
\hline & B1 & - & + & + & - & + & + & - & - & - & + & - & - & 1 & - & - & - & - & - & - & 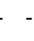 & - & - & - & - & - & - & +-1 & II & 24 \\
\hline & B2 & - & - & + & - & + & + & - & + & + & - & - & + & + & - & - & + & - - & - & - & 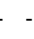 & $-\quad-$ & - & - & - & - & + & + & II & 36 \\
\hline & $S$ & - & + & 1 & - & 1 & 2 & - & + & 2 & + & - & + & 2 & - & - & + & . - & - & - & - & $-\quad-$ & - & - & - & - & 3 & +-3 & III & 44 \\
\hline \multirow[t]{5}{*}{ Malus sylvestris (Qpp) } & A1 & - & - & - & - & - & - & - & - & - & - & - & - & - & - & - & - & - & - & - & - & - & - & - & - & + & - & + & I & 4 \\
\hline & A2 & - & + & - & - & - & + & - & - & - & - & - & - & - & - & - & - & + & ++ & + & +- & - & - & + & - & + & - & + & II & 28 \\
\hline & B1 & - & + & - & - & - & - & - & - & - & - & - & - & - & - & - & - & + & +- & + & +- & - & - & - & - & - & - & + & I & 12 \\
\hline & B2 & + & - & + & - & - & - & - & - & - & - & - & - & - & - & - & - & - & - & - & 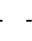 & - & - & - & - & - & - & + & I & 8 \\
\hline & S & + & + & + & - & - & + & - & - & - & - & - & - & - & - & - & - & + & + & + & +- & - & - & + & - & + & - & + & II & 36 \\
\hline Impatiens noli-tangere (Sal) & $\mathrm{C}$ & - & - & - & - & - & - & - & - & - & - & - & - & - & - & - & - & 1 & 15 & $5-$ & 2 & 21 & 1 & 1 & + & - & + & +-5 & II & 28 \\
\hline \multirow[t]{3}{*}{ Padus avium } & B1 & - & - & - & - & - & - & - & - & - & - & - & 1 & 1 & - & - & + & - - & - & - & 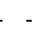 & - & - & + & - & - & - & +-1 & I & 16 \\
\hline & B2 & - & - & - & - & - & - & - & - & - & - & - & + & - & + & - & + & - & - & - & 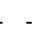 & - & - & - & - & - & - & + & I & 12 \\
\hline & S & - & - & - & - & - & - & - & - & - & - & - & 1 & 1 & + & - & + & - & - & - & . & - & - & + & - & - & - & +-1 & I & 20 \\
\hline \multirow[t]{4}{*}{ Vitis sylvestris (Ulm) } & A2 & + & - & - & - & - & - & - & - & + & - & - & - & - & - & - & - & - & - & - & - & - & - & - & - & - & - & + & I & 8 \\
\hline & B1 & - & + & - & - & - & - & + & - & - & - & - & - & + & - & - & - & - & - & - & . & - & - & - & - & - & - & + & I & 12 \\
\hline & B2 & - & - & - & - & - & - & + & - & - & - & - & - & + & - & - & - & - & - & - & - & - & - & - & - & - & - & + & I & 8 \\
\hline & S & + & + & - & - & - & - & + & - & + & - & - & - & + & - & - & - & - & - & - & - & - & - & - & - & - & - & + & I & 20 \\
\hline \multirow[t]{3}{*}{ Ribes rubrum } & B1 & - & - & - & - & - & - & - & - & - & - & + & - & - & - & - & - & + & +- & - & 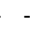 & - & - & - & - & - & - & + & I & 8 \\
\hline & B2 & - & - & - & - & - & - & - & - & - & - & + & - & + & - & - & - & - & - & - & 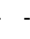 & - & - & - & - & - & + & + & I & 12 \\
\hline & S & - & - & - & - & - & - & - & - & - & - & + & - & + & - & - & - & + & +- & - & - & . & - & - & - & - & + & + & I & 16 \\
\hline Elymus caninus (Pna, Qpp) & $\mathrm{C}$ & - & - & - & + & - & - & - & - & - & - & - & - & - & - & - & - & - & . & - & - & - & - & - & + & - & - & + & I & 8 \\
\hline Equisetum hyemale $(\mathrm{F})$ & $\mathrm{C}$ & - & - & - & - & - & - & - & - & - & - & - & - & - & - & - & - & + & +- & - & - - & - & - & - & - & - & - & + & I & 4 \\
\hline $\begin{array}{l}\text { 1.2.1.2. Fagion sylvaticae } \\
\text { 1.2.1.2.1. Tilio-Acerenion }\end{array}$ & & & & & & & & & & & & & & & & & & & & & & & & & & & & & & \\
\hline Tilia platyphyllos (F) & A1 & - & - & - & - & - & - & - & - & - & - & - & - & - & 1 & - & - & - & 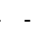 & - & - & - & - & - & - & - & - & 1 & I & 4 \\
\hline & B2 & - & - & - & - & - & - & - & - & - & - & - & - & - & + & - & - & - & 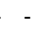 & - & 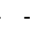 & 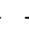 & - & - & - & - & - & + & I & 4 \\
\hline & $S$ & - & - & - & - & - & - & - & - & - & - & - & - & - & 1 & - & - & - & - & - & - & 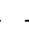 & - & - & - & - & - & 1 & I & 4 \\
\hline 1.3. Quercetea pubescentis-petraeae & & & & & & & & & & & & & & & & & & & & & & & & & & & & & & \\
\hline Prunus spinosa (Pru, Prf) & B1 & - & - & - & - & - & - & - & - & - & - & - & + & + & - & + & - & - & . & + & +- & - & - & - & - & - & - & + & I & 16 \\
\hline & B2 & - & - & - & - & + & - & - & - & - & - & - & - & - & - & - & + & - & 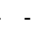 & 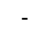 & 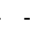 & 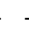 & - & - & - & - & - & + & I & 8 \\
\hline & $\mathrm{S}$ & - & - & - & - & + & - & - & - & - & - & - & + & + & - & + & + & - - & . & . & + & 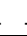 & - & - & - & - & - & + & II & 24 \\
\hline
\end{tabular}


Kitaibelia 25(1): 57-78.

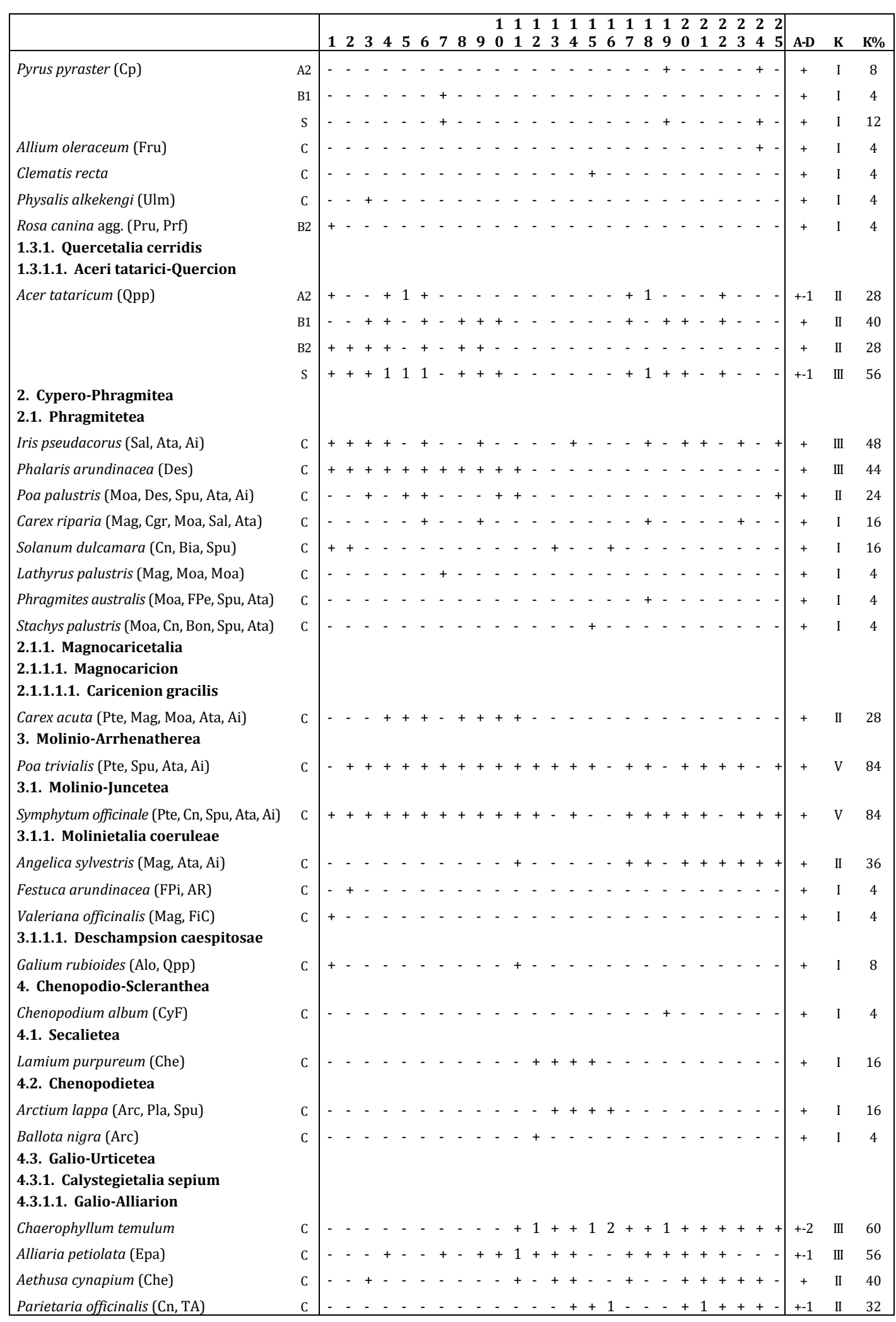


KEVEY (2020): A Csepel-sziget fehérnyár-ligetei

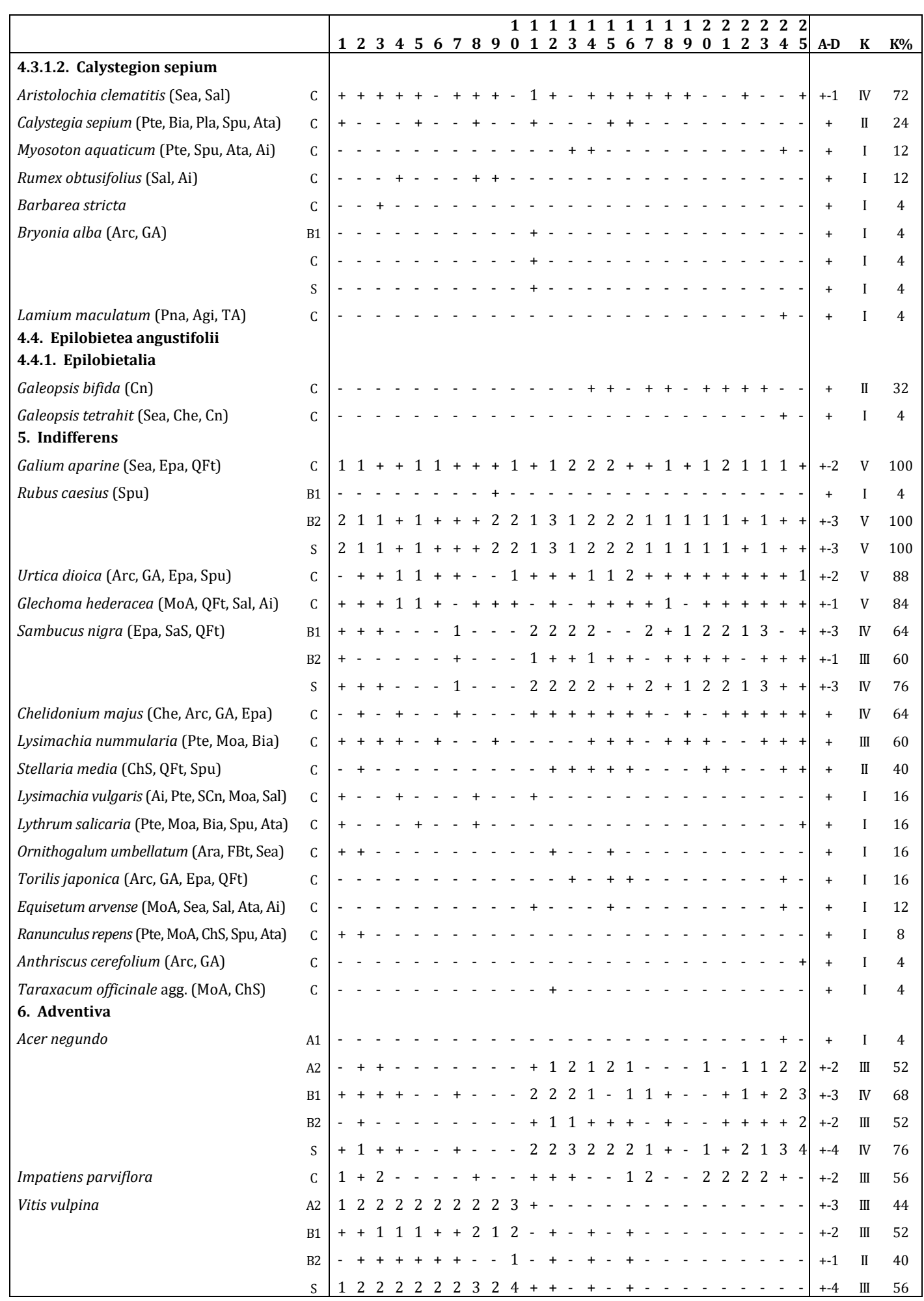


Kitaibelia 25(1): 57-78.

\begin{tabular}{|c|c|c|c|c|c|c|c|c|c|c|c|c|c|c|c|c|c|c|c|c|c|c|c|c|c|c|c|c|c|c|}
\hline & & 1 & & 3 & 4 & 5 & 6 & 7 & 8 & 9 & $\begin{array}{l}\mathbf{1} \\
\mathbf{0}\end{array}$ & $\begin{array}{l}1 \\
1 \\
\end{array}$ & $\begin{array}{l}1 \\
2 \\
\end{array}$ & $\begin{array}{l}1 \\
3 \\
\end{array}$ & $\begin{array}{l}1 \\
4 \\
\end{array}$ & $\begin{array}{l}1 \\
5 \\
\end{array}$ & $\begin{array}{l}1 \\
6 \\
\end{array}$ & $\begin{array}{l}1 \\
7 \\
\end{array}$ & $\begin{array}{l}1 \\
8 \\
\end{array}$ & $\begin{array}{l}11 \\
39 \\
\end{array}$ & $\begin{array}{l}12 \\
90 \\
\end{array}$ & & & & & $\begin{array}{ll}25 \\
455 \\
\end{array}$ & $\mathrm{~A}-1$ & & $\mathbf{K}$ & K\% \\
\hline \multirow[t]{4}{*}{ Celtis occidentalis } & A2 & - & - & - & - & - & - & - & - & - & - & - & + & 1 & - & - & - & - & - & - & - & - & . & 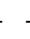 & - & -+ & + & & I & 12 \\
\hline & B1 & + & + & + & + & - & - & - & - & - & - & - & - & 1 & - & - & - & - & - & - & - & 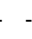 & - & - & - & ++ & + & & II & 28 \\
\hline & B2 & - & + & - & - & - & - & - & + & - & + & - & + & - & - & - & - & - & - & - & - & - & . & - & - & $-\quad-$ & + & & I & 16 \\
\hline & S & + & + & + & + & - & - & - & + & - & + & - & + & 2 & - & - & - & - & - & - & - & 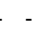 & - & - & - & ++ & +- & & II & 40 \\
\hline \multirow[t]{4}{*}{ Morus alba } & A2 & + & - & - & 1 & - & - & - & - & - & - & - & + & + & - & - & - & - & - & - & - & - & - & - & - & $-\quad-$ & +- & & I & 16 \\
\hline & B1 & - & - & - & + & - & - & - & - & - & - & - & + & + & + & + & + & - & - & + & - & - & . & - & - & - & + & & II & 32 \\
\hline & B2 & - & - & - & + & - & - & - & - & - & - & - & + & - & - & - & + & - & - & - & - & - & . & - & - & - & + & & I & 12 \\
\hline & S & + & - & - & 1 & - & - & - & - & - & - & - & 1 & + & + & + & + & - & - & + & - & - & - & - & - & $-\quad+$ & + & -1 & II & 36 \\
\hline \multirow[t]{5}{*}{ Robinia pseudo-acacia } & $\mathrm{A} 1$ & - & - & - & - & - & - & - & - & - & - & - & - & - & - & - & - & - & - & + & + & +- & - & + & - & +- & + & & I & 16 \\
\hline & A2 & - & - & - & - & - & - & - & - & - & - & - & + & - & - & - & - & - & - & - & - & - & . & - & - & - & + & & I & 4 \\
\hline & B1 & - & - & - & - & - & - & - & - & - & - & - & + & + & - & - & - & - & - & - & - & - & . & 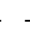 & - & +- & + & & I & 12 \\
\hline & B2 & - & - & - & - & - & - & - & - & - & - & - & - & - & - & - & + & - & - & + & - & - & . & - & - & +- & + & & I & 12 \\
\hline & S & - & - & - & - & - & - & - & - & - & - & - & + & + & - & - & + & - & - & + & + & +- & . & + & & $1-$ & +- & & II & 28 \\
\hline Aster $\times$ salignus & $\mathrm{C}$ & - & + & - & - & - & - & - & - & - & - & - & 1 & + & + & + & + & - & - & - & - & - & . & - & - & - & +- & & II & 24 \\
\hline \multirow[t]{3}{*}{ Juglans regia } & B1 & - & - & - & - & - & - & + & - & - & - & - & + & - & - & - & - & - & - & - & - & . & . & 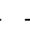 & - & - & + & & I & 8 \\
\hline & B2 & - & - & - & - & - & - & - & - & - & - & + & - & - & - & - & + & - & - & - & - & + & + & 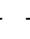 & - & - & + & & I & 16 \\
\hline & S & - & - & - & - & - & - & + & - & - & - & + & + & - & - & - & + & - & - & - & - & + & + & 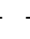 & - & $-\quad+$ & + & & II & 24 \\
\hline \multirow[t]{4}{*}{ Fraxinus pennsylvanica } & A2 & - & - & - & - & - & - & - & - & - & - & - & - & - & - & - & + & - & - & - & - & . & . & 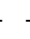 & - & - & + & & I & 4 \\
\hline & B1 & - & - & - & - & - & - & - & - & - & - & - & - & - & - & - & + & - & - & - & - & . & . & 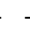 & - & - & & + & I & 4 \\
\hline & B2 & - & - & - & - & - & - & - & - & - & - & - & - & - & + & - & + & - & - & - & - & - & . & - & - & - & + & + & I & 12 \\
\hline & S & - & - & - & - & - & - & - & - & - & - & - & - & - & + & - & 1 & - & - & - & - & - & . & - & - & $-\quad+$ & & -1 & I & 12 \\
\hline \multirow[t]{3}{*}{ Juglans nigra } & B1 & - & - & - & - & - & - & - & - & - & - & - & - & - & - & - & - & - & - & - & + & +- & . & + & - & $-\quad-$ & + & + & I & 8 \\
\hline & B2 & - & - & - & - & - & - & - & - & - & - & - & - & - & + & - & - & - & - & - & - & - & - - & - & - & - - & & + & I & 4 \\
\hline & S & - & - & - & - & - & - & - & - & - & - & - & - & - & + & - & - & - & - & - & + & +- & . & + & - & $-\quad-$ & & + & I & 12 \\
\hline Solidago gigantea & $\mathrm{C}$ & - & - & - & - & - & - & - & - & - & - & + & - & - & - & - & - & - & - & - & - & - & - & - & + & +- & & + & I & 12 \\
\hline \multirow[t]{3}{*}{ Amorpha fruticosa } & B1 & - & - & - & - & - & - & - & - & - & - & + & - & - & - & + & - & - & - & - & - & - & - & 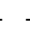 & - & - - & & + & I & 8 \\
\hline & B2 & - & - & - & - & - & - & - & - & - & - & - & - & - & - & + & - & - & - & - & - & 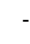 & 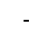 & 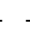 & - & - - - & & + & I & 4 \\
\hline & $\mathrm{S}$ & - & - & - & - & - & - & - & - & - & - & + & - & - & - & + & - - & - & - & - & - & - & 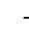 & 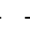 & - & - & & + & I & 8 \\
\hline Populus $\times$ euramericana & $\mathrm{A} 1$ & - & - & - & - & - & - & - & - & - & - & - & - & - & 1 & - & - & - & - & - & - & - & - & - & - & - & & -2 & I & 8 \\
\hline \multirow[t]{3}{*}{ Ailanthus altissima } & B1 & - & - & - & - & - & - & - & - & - & - & - & - & + & - & - & - & - & - & - & - & - & . & - & - & $-\quad-$ & & + & I & 4 \\
\hline & B2 & - & - & - & - & - & - & - & - & - & - & - & - & + & - & - & - & - & - & - & - & - & - & - & - & $-\quad-$ & & + & I & 4 \\
\hline & S & - & - & - & - & - & - & - & - & - & - & - & - & + & - & - & - & - & - & - & - & - & . & - & - & $-\quad-$ & & + & I & 4 \\
\hline Echinocystis lobata & $\mathrm{C}$ & - & - & - & - & - & - & - & - & - & - & - & - & - & - & - & + & - - & - & - & - & . & - & - & - & - & & + & I & 4 \\
\hline Oxalis stricta & $\mathrm{C}$ & - & - & - & - & - & - & - & - & - & - & - & - & - & - & + & - - & - & - & - & - & - & . & - & - & $-\quad-$ & + & + & I & 4 \\
\hline Parthenocissus inserta & B2 & - & - & - & - & - & - & - & - & - & - & + & - & - & - & - & - & - & - & - & - & . & - & - - & - & - & & + & I & 4 \\
\hline Stenactis annua & C & - & - & - & - & - & - & - & - & - & - & - & - & - & - & - & - & - & - & - & - & . & - - & & + & - & & + & I & 4 \\
\hline
\end{tabular}


2. táblázat Felvételi adatok I.

Table 2 Data of the relevés

\begin{tabular}{|c|c|c|c|c|c|c|c|c|c|c|c|c|c|c|c|c|c|c|c|c|c|c|c|c|c|}
\hline Minta sorszáma & 1 & 2 & 3 & 4 & 5 & 6 & 7 & 8 & 9 & 10 & 11 & 12 & 13 & 14 & 15 & 16 & 17 & 18 & 19 & 20 & 21 & 22 & 23 & 24 & 25 \\
\hline Minta felvételi sorszáma & 1853 & 1854 & 1870 & 1871 & 1872 & 1873 & 1874 & 1907 & 1908 & 1909 & 1910 & $|17023|$ & 317024 & 17025 & 17026 & 517027 & 4279 & 4280 & 4282 & 3785 & 3786 & 4305 & 4313 & 4288 & 1851 \\
\hline Felvételi évszám 1. & 1998 & 1998 & 1998 & 1998 & 1998 & 1998 & 1998 & 1998 & 1998 & 1998 & 1998 & 2012 & 2012 & 2012 & 2012 & 2012 & 1987 & 1987 & 1987 & 1988 & 1988 & 1988 & 1988 & 1983 & 1998 \\
\hline Felvételi időpont 1. & 04.14 & 04.14 & 04.14 & 04.14 & 04.14 & 04.14 & 04.16 & 04.16 & 04.16 & 04.16 & 04.16 & 04.23 & 04.23 & 04.23 & 04.23 & 04.23 & 04.22 & 04.22 & 04.22 & 04.06 & 04.06 & 04.06 & 04.06 & 04.12 & 04.16 \\
\hline Felvételi évszám 2. & 1998 & 1998 & 1998 & 1998 & 1998 & 1998 & 1998 & 1998 & 1998 & 1998 & 1998 & 2012 & 2012 & 2012 & 2012 & 2012 & 1987 & 1987 & 1987 & 1988 & 1988 & 1988 & 1988 & 1983 & 1998 \\
\hline Felvételi időpont 2. & 07.21 & 07.21 & 07.21 & 07.21 & 07.21 & 07.21 & 07.21 & 07.21 & 07.21 & 07.21 & 07.23 & 07.03 & 07.03 & 07.03 & 07.03 & 07.03 & 07.08 & 07.08 & 07.08 & 06.22 & 06.22 & 07.13 & 07.13 & 09.06 & 07.22 \\
\hline $\begin{array}{l}\text { Tengerszint feletti } \\
\text { magasság }\end{array}$ & 100 & 100 & 100 & 100 & 100 & 100 & 100 & 100 & 100 & 100 & 100 & 98 & 98 & 98 & 98 & 98 & 99 & 99 & 99 & 98 & 98 & 98 & 98 & 97 & 95 \\
\hline Lejtőszög (fok) & 0 & 0 & 0 & 0 & 0 & 0 & 0 & 0 & 0 & 0 & 0 & 0 & 0 & 0 & 0 & 0 & 0 & 0 & 0 & 0 & 0 & 0 & 0 & 0 & 0 \\
\hline $\begin{array}{l}\text { Felső lombkoronaszint } \\
\text { borítása (\%) }\end{array}$ & 60 & 50 & 50 & 60 & 70 & 50 & 60 & 60 & 60 & 60 & 60 & 60 & 75 & 75 & 70 & 70 & 75 & 70 & 60 & 80 & 80 & 80 & 70 & 75 & 60 \\
\hline $\begin{array}{l}\begin{array}{l}\text { Felső lombkoronaszint } \\
\text { magassága }(\mathrm{m})\end{array} \\
\end{array}$ & 25 & 27 & 27 & 25 & 28 & 25 & 27 & 28 & 27 & 27 & 28 & 30 & 30 & 30 & 30 & 30 & 26 & 28 & 22 & 27 & 28 & 25 & 28 & 26 & 27 \\
\hline Átlagos törzsátmérő (cm) & 60 & 65 & 65 & 60 & 65 & 65 & 75 & 60 & 60 & 65 & 55 & 60 & 65 & 60 & 60 & 65 & 50 & 60 & 40 & 55 & 55 & 45 & 60 & 55 & 45 \\
\hline $\begin{array}{l}\text { Alsó lombkoronaszint } \\
\text { borítása (\%) }\end{array}$ & 40 & 60 & 50 & 50 & 40 & 60 & 60 & 50 & 50 & 40 & 20 & 30 & 30 & 30 & 40 & 25 & 40 & 45 & 50 & 30 & 25 & 40 & 40 & 40 & 50 \\
\hline $\begin{array}{l}\text { Alsó lombkoronaszint } \\
\text { magassága }(\mathrm{m})\end{array}$ & 18 & 20 & 20 & 18 & 16 & 20 & 20 & 15 & 20 & 15 & 16 & 18 & 15 & 20 & 17 & 18 & 18 & 15 & 15 & 20 & 18 & 17 & 15 & 14 & 15 \\
\hline Cserjeszint borítása (\%) & 70 & 60 & 75 & 50 & 50 & 60 & 50 & 75 & 50 & 60 & 40 & 70 & 60 & 60 & 50 & 30 & 40 & 50 & 50 & 60 & 50 & 30 & 50 & 45 & 50 \\
\hline Cserjeszint magassága (m) & 3 & 3 & 4 & 3 & 2.5 & 3 & 3 & 3 & 3 & 3 & 2 & 3 & 2,5 & 3,5 & 2 & 1,5 & 2.5 & 2 & 4 & 3 & 3.5 & 3.5 & 3 & 3.5 & 2.5 \\
\hline Újulat borítása (\%) & 30 & 5 & 5 & 5 & 5 & 5 & 5 & 3 & 25 & 20 & 10 & 35 & 20 & 25 & 25 & 30 & 5 & 2 & 5 & 5 & 5 & 1 & 5 & 5 & 10 \\
\hline Gyepszint borítása (\%) & 25 & 40 & 60 & 60 & 80 & 70 & 80 & 50 & 40 & 75 & 80 & 80 & 85 & 70 & 70 & 80 & 80 & 90 & 90 & 85 & 90 & 90 & 60 & 75 & 90 \\
\hline $\begin{array}{l}\text { Felvételi terület nagysága } \\
\left(\mathrm{m}^{2}\right)\end{array}$ & 1600 & 1600 & 1600 & 1600 & 1600 & 1600 & 1600 & 1600 & 1600 & 1600 & $|1600|$ & 1600 & 1600 & 1600 & 1600 & 1600 & 1600 & 1600 & 1600 & 1600 & 1600 & 1200 & 1600 & 1600 & 1600 \\
\hline
\end{tabular}


3. táblázat Felvételi adatok II.

Table 3 Data of the relevés II.

\begin{tabular}{|c|c|c|c|c|c|c|c|c|}
\hline \multicolumn{2}{|c|}{ Kvadrát } & \multirow{2}{*}{$\begin{array}{c}\text { Település } \\
\text { Budapest } \\
\end{array}$} & \multirow{2}{*}{$\begin{array}{c}\text { Dúlő } \\
\text { Háros-sziget } \\
\end{array}$} & \multicolumn{2}{|c|}{ Földrajzi koordináták } & \multirow{2}{*}{$\begin{array}{c}\text { Alapkőzet } \\
\text { homokos öntésföld }\end{array}$} & \multirow{2}{*}{$\begin{array}{c}\text { Talajtípus } \\
\text { nyers öntéstalaj }\end{array}$} & \multirow{2}{*}{$\begin{array}{c}\text { Szerző } \\
\text { KEVEY \& HUSZÁR (1999) }\end{array}$} \\
\hline 1 & 1853 & & & $47^{\circ} 24^{\prime} 02,02^{\prime \prime}$ & $19^{\circ} 01^{\prime} 38,88^{\prime \prime}$ & & & \\
\hline 2 & 1854 & Budapest & Háros-sziget & $47^{\circ} 23^{\prime} 57,26^{\prime \prime}$ & $19^{\circ} 01^{\prime} 40,79^{\prime \prime}$ & homokos öntésföld & nyers öntéstalaj & KEVEY \& HUSZÁR (1999) \\
\hline 3 & 1870 & Budapest & Háros-sziget & $47^{\circ} 23^{\prime} 53,44^{\prime \prime}$ & $19^{\circ} 01^{\prime} 45,50^{\prime \prime}$ & homokos öntésföld & nyers öntéstalaj & KEVEY \& HUSZÁR (1999) \\
\hline 4 & 1871 & Budapest & Háros-sziget & $47^{\circ} 23^{\prime} 50,44^{\prime \prime}$ & $19^{\circ} 01^{\prime} 34,34 "$ & homokos öntésföld & nyers öntéstalaj & KEVEY \& HuSZÁr (1999) \\
\hline 5 & 1872 & Budapest & Háros-sziget & $47^{\circ} 23^{\prime} 48,64^{\prime \prime}$ & $19^{\circ} 01^{\prime} 19,83^{\prime \prime}$ & homokos öntésföld & nyers öntéstalaj & KEVEY \& HuSZÁR (1999) \\
\hline 6 & 1873 & Budapest & Háros-sziget & $47^{\circ} 23^{\prime} 45,03^{\prime \prime}$ & $19^{\circ} 01^{\prime} 14,96^{\prime \prime}$ & homokos öntésföld & nyers öntéstalaj & KEVEY \& HuSZÁr (1999) \\
\hline 7 & 1874 & Budapest & Háros-sziget & $47^{\circ} 23^{\prime} 59,64^{\prime \prime}$ & $19^{\circ} 01^{\prime} 28,26^{\prime \prime}$ & homokos öntésföld & nyers öntéstalaj & KEVEY \& HUSZÁR (1999) \\
\hline 8 & 1907 & Budapest & Háros-sziget & $47^{\circ} 23^{\prime} 49,48^{\prime \prime}$ & $19^{\circ} 01^{\prime} 14,15^{\prime \prime}$ & homokos öntésföld & nyers öntéstalaj & KEVEY \& HuSZÁR (1999) \\
\hline 9 & 1908 & Budapest & Háros-sziget & $47^{\circ} 23^{\prime} 47,99^{\prime \prime}$ & $19^{\circ} 01^{\prime} 05,08^{\prime \prime}$ & homokos öntésföld & nyers öntéstalaj & KEVEY \& HuSZÁR (1999) \\
\hline 10 & 1909 & Budapest & Háros-sziget & $47^{\circ} 23^{\prime} 46,54^{\prime \prime}$ & $19^{\circ} 01^{\prime} 18,17^{\prime \prime}$ & homokos öntésföld & nyers öntéstalaj & KEVEY \& HuSZÁR (1999) \\
\hline 11 & 1910 & Százhalombatta & Kacsás-sziget & $47^{\circ} 18^{\prime} 15,46^{\prime \prime}$ & $18^{\circ} 55^{\prime} 25,32^{\prime \prime}$ & homokos öntésföld & nyers öntéstalaj & Kevey ined. \\
\hline 12 & 17023 & Ercsi & Sziget & $47^{\circ} 14^{\prime} 13,72^{\prime \prime}$ & $18^{\circ} 54^{\prime} 10,54^{\prime \prime}$ & homokos öntésföld & nyers öntéstalaj & Kevey ined. \\
\hline 13 & 17024 & Ercsi & Sziget & $47^{\circ} 14^{\prime} 17,36^{\prime \prime}$ & $18^{\circ} 54^{\prime} 12,50^{\prime \prime}$ & homokos öntésföld & nyers öntéstalaj & Kevey ined. \\
\hline 14 & 17025 & Ercsi & Sziget & $47^{\circ} 14^{\prime} 23,33^{\prime \prime}$ & $18^{\circ} 54^{\prime} 14,82^{\prime \prime}$ & homokos öntésföld & nyers öntéstalaj & Kevey ined. \\
\hline 15 & 17026 & Ercsi & Sziget & $47^{\circ} 14^{\prime} 29,77^{\prime \prime}$ & $18^{\circ} 54^{\prime} 27,44^{\prime \prime}$ & homokos öntésföld & nyers öntéstalaj & Kevey ined. \\
\hline 16 & 17027 & Ercsi & Sziget & $47^{\circ} 14^{\prime} 12,10^{\prime \prime}$ & $18^{\circ} 54^{\prime} 24,11^{\prime \prime}$ & homokos öntésföld & nyers öntéstalaj & Kevey ined. \\
\hline 17 & 4279 & Szigetújfalu & Újfalusi-erdő & $47^{\circ} 14^{\prime} 08,38^{\prime \prime}$ & $18^{\circ} 55^{\prime} 14,28^{\prime \prime}$ & homokos öntésföld & nyers öntéstalaj & Kevey ined. \\
\hline 18 & 4280 & Szigetújfalu & Újfalusi-erdő & $47^{\circ} 14^{\prime} 27,74^{\prime \prime}$ & $18^{\circ} 54^{\prime} 59,67^{\prime \prime}$ & homokos öntésföld & nyers öntéstalaj & Kevey ined. \\
\hline 19 & 4282 & Szigetújfalu & Újfalusi-erdő & $47^{\circ} 15^{\prime} 05,14^{\prime \prime}$ & $18^{\circ} 55^{\prime} 14,48^{\prime \prime}$ & homokos öntésföld & nyers öntéstalaj & Kevey ined. \\
\hline 20 & 3785 & Ráckeve & Besnyő & $47^{\circ} 10^{\prime} 59,26^{\prime \prime}$ & $18^{\circ} 53^{\prime} 18,16^{\prime \prime}$ & homokos öntésföld & nyers öntéstalaj & Kevey ined. \\
\hline 21 & 3786 & Ráckeve & Besnyő & $47^{\circ} 10^{\prime} 59,09^{\prime \prime}$ & $18^{\circ} 53^{\prime} 21,31^{\prime \prime}$ & homokos öntésföld & nyers öntéstalaj & Kevey ined. \\
\hline 22 & 4305 & Ráckeve & Besnyő & $47^{\circ} 10^{\prime} 55,88^{\prime \prime}$ & $18^{\circ} 53^{\prime} 09,60^{\prime \prime}$ & homokos öntésföld & nyers öntéstalaj & Kevey ined. \\
\hline 23 & 4313 & Ráckeve & Besnyő & $47^{\circ} 11^{\prime} 02,25^{\prime \prime}$ & $18^{\circ} 53^{\prime} 09,55^{\prime \prime}$ & homokos öntésföld & nyers öntéstalaj & Kevey ined. \\
\hline 24 & 4288 & Lórév & Rókás & $47^{\circ} 06^{\prime} 06,93^{\prime \prime}$ & $18^{\circ} 53^{\prime} 47,81^{\prime \prime}$ & homokos öntésföld & nyers öntéstalaj & Kevey ined. \\
\hline 25 & 1851 & Rácalmás & Kis-sziget & $47^{\circ} 00^{\prime} 08,36^{\prime \prime}$ & $18^{\circ} 56^{\prime} 52,61 "$ & homokos öntésföld & nyers öntéstalaj & Kevey ined. \\
\hline
\end{tabular}




\section{4. táblázat Karakterfajok aránya}

Table 4 Percentage of characteristic species

P-Szk: Senecioni sarracenici-Populetum albae, Szigetköz (KeVEY 2008: 25 felv.)

P-Cs: Senecioni sarracenici-Populetum albae, Csepel-sziget (KeveY \& HuszáR 1999: 10 felv.; Kevey ined.: 15 felv.)

P-Msz: Senecioni sarracenici-Populetum albae, Mohácsi-sziget (Kevey 2017: 25 felv.) U-Cs: Scillo vindobonensis-Ulmetum, Csepel-sziget (Kevey ined.: 12 felv.)

\begin{tabular}{|c|c|c|c|c|c|c|c|c|}
\hline \multirow{2}{*}{ Szüntaxon } & \multicolumn{4}{|c|}{ Csoportrészesedés } & \multicolumn{4}{|c|}{ Csoporttömeg } \\
\hline & P-Szk & P-Cs & P-Msz & U-Cs & P-Szk & P-Cs & P-Msz & U-Cs \\
\hline Querco-Fagea & 0.00 & 0.00 & 0.00 & 0.00 & 0.00 & 0.00 & 0.00 & 0.00 \\
\hline Salicetea purpureae & 0.00 & 0.00 & 0.00 & 0.00 & 0.00 & 0.00 & 0.00 & 0.00 \\
\hline Salicetalia purpureae & 3.95 & 4.00 & 3.46 & 1.10 & 1.89 & 4.85 & 5.30 & 0.15 \\
\hline Salicion triandrae & 0.00 & 0.00 & 0.00 & 0.00 & 0.00 & 0.00 & 0.00 & 0.00 \\
\hline Salicenion elaeagno-daphnoidis & 0.08 & 0.00 & 0.00 & 0.00 & 0.01 & 0.00 & 0.00 & 0.00 \\
\hline Salicion triandrae s.l. & 0.08 & 0.00 & 0.00 & 0.00 & 0.01 & 0.00 & 0.00 & 0.00 \\
\hline Salicion albae & 6.42 & 4.52 & 4.41 & 2.30 & 12.84 & 10.01 & 11.15 & 0.70 \\
\hline Populenion nigro-albae & 1.14 & 0.44 & 0.70 & 0.45 & 0.61 & 0.04 & 0.07 & 0.05 \\
\hline Salicion albae s.l. & 7.56 & 4.96 & 5.11 & 2.75 & 13.45 & 10.05 & 11.22 & 0.75 \\
\hline Salicetalia purpureae s.l. & 11.59 & 8.96 & 8.57 & 3.85 & 15.35 & 14.90 & 16.52 & 0.90 \\
\hline Salicetea purpureae s.l. & 11.59 & 8.96 & 8.57 & 3.85 & 15.35 & 14.90 & 16.52 & 0.90 \\
\hline Alnetea glutinosae & 0.00 & 0.00 & 0.00 & 0.00 & 0.00 & 0.00 & 0.00 & 0.00 \\
\hline Alnetalia glutinosae & 1.86 & 2.57 & 2.42 & 2.14 & 0.40 & 0.91 & 1.76 & 3.29 \\
\hline Alnetea glutinosae s.l. & 1.86 & 2.57 & 2.42 & 2.14 & 0.40 & 0.91 & 1.76 & 3.29 \\
\hline Querco-Fagetea & 9.76 & 16.02 & 12.51 & 19.22 & 21.35 & 25.17 & 20.00 & 26.63 \\
\hline Fagetalia sylvaticae & 5.32 & 5.77 & 5.28 & 7.04 & 1.61 & 2.93 & 1.03 & 4.51 \\
\hline Alnion incanae & 10.33 & 10.29 & 10.99 & 6.67 & 14.51 & 14.11 & 13.67 & 11.84 \\
\hline Alnenion glutinosae-incanae & 0.85 & 0.02 & 0.00 & 0.04 & 0.97 & 0.00 & 0.00 & 0.00 \\
\hline Ulmenion & 0.93 & 1.96 & 2.19 & 1.48 & 0.21 & 2.68 & 1.68 & 1.69 \\
\hline Alnion incanae s.l. & 12.11 & 12.27 & 13.18 & 8.19 & 15.69 & 16.79 & 15.35 & 13.53 \\
\hline Fagion sylvaticae & 0.00 & 0.00 & 0.00 & 0.00 & 0.00 & 0.00 & 0.00 & 0.00 \\
\hline Eu-Fagenion & 0.00 & 0.00 & 0.00 & 0.08 & 0.00 & 0.00 & 0.00 & 1.00 \\
\hline Carpinenion betuli & 2.17 & 1.95 & 1.06 & 3.73 & 1.05 & 1.84 & 0.22 & 6.52 \\
\hline Tilio-Acerenion & 0.63 & 0.54 & 0.33 & 0.86 & 0.56 & 0.09 & 0.03 & 0.95 \\
\hline Fagion sylvaticae s.l. & 2.80 & 2.49 & 1.39 & 4.67 & 1.61 & 1.93 & 0.25 & 8.47 \\
\hline Aremonio-Fagion & 0.00 & 0.00 & 0.71 & 0.00 & 0.00 & 0.00 & 0.25 & 0.00 \\
\hline Fagion dacicum & 0.00 & 0.00 & 0.00 & 0.00 & 0.00 & 0.00 & 0.00 & 0.00 \\
\hline Fagetalia sylvaticae s.l. & 20.23 & 20.53 & 20.56 & 19.90 & 18.91 & 21.65 & 16.88 & 26.51 \\
\hline Quercetalia roboris & 0.00 & 0.00 & 0.04 & 0.38 & 0.00 & 0.00 & 0.00 & 0.04 \\
\hline Quercion robori-petraeae & 0.05 & 0.00 & 0.00 & 0.09 & 0.00 & 0.00 & 0.00 & 0.01 \\
\hline Quercetalia roboris s.l. & 0.05 & 0.00 & 0.04 & 0.47 & 0.00 & 0.00 & 0.00 & 0.05 \\
\hline Querco-Fagetea s.l. & 30.04 & 36.55 & 33.11 & 39.59 & 40.26 & 46.82 & 36.88 & 53.19 \\
\hline Quercetea pubescentis-petraeae & 6.48 & 11.10 & 5.46 & 19.22 & 9.09 & 12.84 & 6.38 & 27.10 \\
\hline Orno-Cotinetalia & 0.00 & 0.00 & 0.00 & 0.00 & 0.00 & 0.00 & 0.00 & 0.00 \\
\hline Orno-Cotinion & 0.00 & 0.00 & 0.00 & 0.36 & 0.00 & 0.00 & 0.00 & 1.45 \\
\hline Orno-Cotinetalia s.l. & 0.00 & 0.00 & 0.00 & 0.36 & 0.00 & 0.00 & 0.00 & 1.45 \\
\hline Quercetalia cerridis & 0.00 & 0.00 & 0.00 & 0.13 & 0.00 & 0.00 & 0.00 & 0.01 \\
\hline Aceri tatarici-Quercion & 0.65 & 1.29 & 0.82 & 1.27 & 9.49 & 7.24 & 9.12 & 3.00 \\
\hline Quercetalia cerridis s.l. & 0.65 & 1.29 & 0.82 & 1.40 & 9.49 & 7.24 & 9.12 & 3.01 \\
\hline Prunetalia spinosae & 0.03 & 0.31 & 0.08 & 1.67 & 0.00 & 0.03 & 0.01 & 0.23 \\
\hline Berberidion & 0.00 & 0.00 & 0.00 & 0.00 & 0.00 & 0.00 & 0.00 & 0.00 \\
\hline Prunion fruticosae & 0.03 & 0.20 & 0.08 & 0.52 & 0.00 & 0.02 & 0.01 & 0.11 \\
\hline Prunetalia spinosae s.l. & 0.06 & 0.51 & 0.16 & 2.19 & 0.00 & 0.05 & 0.02 & 0.34 \\
\hline Quercetea pubescentis-petraeae s.l. & 7.19 & 12.90 & 6.44 & 23.17 & 18.58 & 20.13 & 15.52 & 31.90 \\
\hline Querco-Fagea s.l. & 50.68 & 60.98 & 50.54 & 68.75 & 74.59 & 82.76 & 70.68 & 89.28 \\
\hline
\end{tabular}


Kitaibelia 25(1): 57-78.

\begin{tabular}{|c|c|c|c|c|c|c|c|c|}
\hline \multirow{2}{*}{ Szüntaxon } & \multicolumn{4}{|c|}{ Csoportrészesedés } & \multicolumn{4}{|c|}{ Csoporttömeg } \\
\hline & P-Szk & P-Cs & P-Msz & U-Cs & P-Szk & P-Cs & P-Msz & U-Cs \\
\hline Abieti-Piceea & 0.00 & 0.00 & 0.00 & 0.00 & 0.00 & 0.00 & 0.00 & 0.00 \\
\hline Vaccinio-Piceetea & 0.00 & 0.00 & 0.00 & 0.00 & 0.00 & 0.00 & 0.00 & 0.00 \\
\hline Pino-Quercetalia & 0.00 & 0.00 & 0.00 & 0.00 & 0.00 & 0.00 & 0.00 & 0.00 \\
\hline Pino-Quercion & 0.00 & 0.00 & 0.04 & 0.47 & 0.00 & 0.00 & 0.00 & 0.05 \\
\hline Pino-Quercetalia s.l. & 0.00 & 0.00 & 0.04 & 0.47 & 0.00 & 0.00 & 0.00 & 0.05 \\
\hline Vaccinio-Piceetea s.l. & 0.00 & 0.00 & 0.04 & 0.47 & 0.00 & 0.00 & 0.00 & 0.05 \\
\hline Abieti-Piceea s.l. & 0.00 & 0.00 & 0.04 & 0.47 & 0.00 & 0.00 & 0.00 & 0.05 \\
\hline Cypero-Phragmitea & 0.00 & 0.00 & 0.00 & 0.00 & 0.00 & 0.00 & 0.00 & 0.00 \\
\hline Phragmitetea & 3.66 & 2.33 & 2.56 & 0.61 & 0.66 & 0.21 & 0.31 & 0.06 \\
\hline Nasturtio-Glycerietalia & 0.00 & 0.00 & 0.00 & 0.00 & 0.00 & 0.00 & 0.00 & 0.00 \\
\hline Glycerio-Sparganion & 0.21 & 0.00 & 0.00 & 0.00 & 0.02 & 0.00 & 0.00 & 0.00 \\
\hline Nasturtio-Glycerietalia s.l. & 0.21 & 0.00 & 0.00 & 0.00 & 0.02 & 0.00 & 0.00 & 0.00 \\
\hline Magnocaricetalia & 0.00 & 0.00 & 0.00 & 0.00 & 0.00 & 0.00 & 0.00 & 0.00 \\
\hline Magnocaricion & 0.57 & 0.39 & 0.24 & 0.32 & 0.07 & 0.04 & 0.02 & 0.03 \\
\hline Caricenion gracilis & 0.04 & 0.15 & 0.11 & 0.05 & 0.00 & 0.01 & 0.01 & 0.01 \\
\hline Magnocaricion s.l. & 0.61 & 0.54 & 0.35 & 0.37 & 0.07 & 0.05 & 0.03 & 0.04 \\
\hline Magnocaricetalia s.l. & 0.61 & 0.54 & 0.35 & 0.37 & 0.07 & 0.05 & 0.03 & 0.04 \\
\hline Phragmitetea s.l. & 4.48 & 2.87 & 2.91 & 0.98 & 0.75 & 0.26 & 0.34 & 0.10 \\
\hline Isoëto-Nanojuncetea & 0.00 & 0.00 & 0.00 & 0.00 & 0.00 & 0.00 & 0.00 & 0.00 \\
\hline Nanocyperetalia & 0.00 & 0.00 & 0.00 & 0.00 & 0.00 & 0.00 & 0.00 & 0.00 \\
\hline Nanocyperion flavescentis & 0.09 & 0.00 & 0.06 & 0.00 & 0.01 & 0.00 & 0.01 & 0.00 \\
\hline Nanocyperetalia s.l. & 0.09 & 0.00 & 0.06 & 0.00 & 0.01 & 0.00 & 0.01 & 0.00 \\
\hline Isoëto-Nanojuncetea s.l. & 0.09 & 0.00 & 0.06 & 0.00 & 0.01 & 0.00 & 0.01 & 0.00 \\
\hline Cypero-Phragmitea s.l. & 4.57 & 2.87 & 2.97 & 0.98 & 0.76 & 0.26 & 0.35 & 0.10 \\
\hline Oxycocco-Caricea nigrae & 0.00 & 0.00 & 0.00 & 0.00 & 0.00 & 0.00 & 0.00 & 0.00 \\
\hline Scheuchzerio-Caricetea nigrae & 0.00 & 0.00 & 0.00 & 0.00 & 0.00 & 0.00 & 0.00 & 0.00 \\
\hline Scheuchzerio-Caricetalia nigrae & 0.01 & 0.06 & 0.07 & 0.00 & 0.00 & 0.01 & 0.01 & 0.00 \\
\hline Scheuchzerio-Caricetea nigrae s.l. & 0.01 & 0.06 & 0.07 & 0.00 & 0.00 & 0.01 & 0.01 & 0.00 \\
\hline Oxycocco-Caricea nigrae s.l. & 0.01 & 0.06 & 0.07 & 0.00 & 0.00 & 0.01 & 0.01 & 0.00 \\
\hline Molinio-Arrhenatherea & 1.20 & 0.81 & 1.47 & 0.38 & 0.74 & 0.09 & 0.38 & 0.04 \\
\hline Molinio-Juncetea & 1.20 & 0.94 & 1.05 & 0.48 & 0.14 & 0.08 & 0.11 & 0.05 \\
\hline Molinietalia coeruleae & 0.69 & 0.28 & 0.21 & 0.22 & 0.08 & 0.03 & 0.03 & 0.02 \\
\hline Molinion coeruleae & 0.00 & 0.00 & 0.00 & 0.04 & 0.00 & 0.00 & 0.00 & 0.00 \\
\hline Deschampsion caespitosae & 1.22 & 1.28 & 1.18 & 0.18 & 0.26 & 0.41 & 0.28 & 0.02 \\
\hline Filipendulo-Cirsion oleracei & 0.09 & 0.03 & 0.04 & 0.10 & 0.01 & 0.00 & 0.00 & 0.01 \\
\hline Alopecurion pratensis & 0.19 & 0.06 & 0.23 & 0.10 & 0.02 & 0.01 & 0.02 & 0.01 \\
\hline Molinietalia coeruleae s.l. & 2.19 & 1.65 & 1.66 & 0.64 & 0.37 & 0.45 & 0.33 & 0.06 \\
\hline Molinio-Juncetea s.l. & 3.39 & 2.59 & 2.71 & 1.12 & 0.51 & 0.53 & 0.44 & 0.11 \\
\hline Arrhenatheretea & 0.00 & 0.00 & 0.00 & 0.00 & 0.00 & 0.00 & 0.00 & 0.00 \\
\hline Arrhenatheretalia & 0.24 & 0.08 & 0.32 & 0.29 & 0.02 & 0.01 & 0.03 & 0.03 \\
\hline Arrhenatherion elatioris & 0.00 & 0.00 & 0.00 & 0.05 & 0.00 & 0.00 & 0.00 & 0.01 \\
\hline Cynosurion cristati & 0.03 & 0.00 & 0.00 & 0.00 & 0.00 & 0.00 & 0.00 & 0.00 \\
\hline Arrhenatheretalia s.l. & 0.27 & 0.08 & 0.32 & 0.34 & 0.02 & 0.01 & 0.03 & 0.04 \\
\hline Arrhenatheretea s.l. & 0.27 & 0.08 & 0.32 & 0.34 & 0.02 & 0.01 & 0.03 & 0.04 \\
\hline Nardo-Callunetea & 0.00 & 0.00 & 0.00 & 0.00 & 0.00 & 0.00 & 0.00 & 0.00 \\
\hline Nardetalia & 0.00 & 0.00 & 0.00 & 0.00 & 0.00 & 0.00 & 0.00 & 0.00 \\
\hline Nardo-Agrostion tenuis & 0.00 & 0.00 & 0.00 & 0.09 & 0.00 & 0.00 & 0.00 & 0.01 \\
\hline Nardetalia s.l. & 0.00 & 0.00 & 0.00 & 0.09 & 0.00 & 0.00 & 0.00 & 0.01 \\
\hline Nardo-Callunetea s.l. & 0.00 & 0.00 & 0.00 & 0.09 & 0.00 & 0.00 & 0.00 & 0.01 \\
\hline Molinio-Arrhenatherea s.l. & 4.86 & 3.48 & 4.50 & 1.93 & 1.27 & 0.63 & 0.85 & 0.20 \\
\hline
\end{tabular}


KEVEY (2020): A Csepel-sziget fehérnyár-ligetei

\begin{tabular}{|c|c|c|c|c|c|c|c|c|}
\hline \multirow{2}{*}{ Szüntaxon } & \multicolumn{4}{|c|}{ Csoportrészesedés } & \multicolumn{4}{|c|}{ Csoporttömeg } \\
\hline & P-Szk & P-Cs & P-Msz & U-Cs & P-Szk & P-Cs & P-Msz & U-Cs \\
\hline Puccinellio-Salicornea & 0.00 & 0.00 & 0.00 & 0.00 & 0.00 & 0.00 & 0.00 & 0.00 \\
\hline Festuco-Puccinellietea & 0.36 & 0.02 & 0.09 & 0.00 & 0.03 & 0.00 & 0.01 & 0.00 \\
\hline Festuco-Puccinellietalia & 0.12 & 0.03 & 0.08 & 0.03 & 0.01 & 0.00 & 0.01 & 0.00 \\
\hline Beckmannion eruciformis & 0.00 & 0.00 & 0.03 & 0.00 & 0.00 & 0.00 & 0.00 & 0.00 \\
\hline Festuco-Puccinellietalia s.l. & 0.12 & 0.03 & 0.11 & 0.03 & 0.01 & 0.00 & 0.01 & 0.00 \\
\hline Festuco-Puccinellietea s.l. & 0.48 & 0.05 & 0.20 & 0.03 & 0.04 & 0.00 & 0.02 & 0.00 \\
\hline Puccinellio-Salicornea s.l. & 0.48 & 0.05 & 0.20 & 0.03 & 0.04 & 0.00 & 0.02 & 0.00 \\
\hline Festuco-Bromea & 0.08 & 0.00 & 0.00 & 0.00 & 0.01 & 0.00 & 0.00 & 0.00 \\
\hline Festucetea vaginatae & 0.00 & 0.00 & 0.00 & 0.00 & 0.00 & 0.00 & 0.00 & 0.00 \\
\hline Festucetalia vaginatae & 0.00 & 0.00 & 0.00 & 0.00 & 0.00 & 0.00 & 0.00 & 0.00 \\
\hline Festucion vaginatae & 0.00 & 0.00 & 0.00 & 0.04 & 0.00 & 0.00 & 0.00 & 0.00 \\
\hline Festucetalia vaginatae s.l. & 0.00 & 0.00 & 0.00 & 0.04 & 0.00 & 0.00 & 0.00 & 0.00 \\
\hline Festucetea vaginatae s.l. & 0.00 & 0.00 & 0.00 & 0.04 & 0.00 & 0.00 & 0.00 & 0.00 \\
\hline Festuco-Brometea & 0.06 & 0.08 & 0.13 & 0.75 & 0.01 & 0.01 & 0.01 & 0.08 \\
\hline Festucetalia valesiacae & 0.00 & 0.00 & 0.03 & 0.31 & 0.00 & 0.00 & 0.00 & 0.03 \\
\hline Festucion rupicolae & 0.00 & 0.04 & 0.00 & 0.26 & 0.00 & 0.00 & 0.00 & 0.03 \\
\hline Cynodonto-Festucenion & 0.00 & 0.04 & 0.08 & 0.00 & 0.00 & 0.00 & 0.01 & 0.00 \\
\hline Festucion rupicolae s.l. & 0.00 & 0.08 & 0.08 & 0.26 & 0.00 & 0.00 & 0.01 & 0.03 \\
\hline Festucetalia valesiacae s.l. & 0.00 & 0.08 & 0.11 & 0.57 & 0.00 & 0.00 & 0.01 & 0.06 \\
\hline Festuco-Brometea s.l. & 0.06 & 0.16 & 0.24 & 1.32 & 0.01 & 0.01 & 0.02 & 0.14 \\
\hline Festuco-Bromea s.l. & 0.14 & 0.16 & 0.24 & 1.36 & 0.02 & 0.01 & 0.02 & 0.14 \\
\hline Chenopodio-Scleranthea & 0.53 & 0.31 & 1.45 & 0.00 & 0.05 & 0.03 & 0.88 & 0.00 \\
\hline Secalietea & 0.75 & 1.35 & 1.44 & 1.63 & 0.23 & 0.46 & 0.78 & 0.29 \\
\hline Secalietalia & 0.00 & 0.00 & 0.00 & 0.00 & 0.00 & 0.00 & 0.00 & 0.00 \\
\hline Caucalidion platycarpos & 0.03 & 0.00 & 0.00 & 0.10 & 0.00 & 0.00 & 0.00 & 0.01 \\
\hline Secalietalia s.l. & 0.03 & 0.00 & 0.00 & 0.10 & 0.00 & 0.00 & 0.00 & 0.01 \\
\hline Secalietea s.l. & 0.78 & 1.35 & 1.44 & 1.73 & 0.23 & 0.46 & 0.78 & 0.30 \\
\hline Chenopodietea & 1.27 & 1.01 & 1.34 & 0.60 & 0.11 & 0.09 & 0.13 & 0.08 \\
\hline Sisymbrietalia & 0.00 & 0.00 & 0.00 & 0.00 & 0.00 & 0.00 & 0.00 & 0.00 \\
\hline Sisymbrion officinalis & 0.12 & 0.00 & 0.00 & 0.00 & 0.01 & 0.00 & 0.00 & 0.00 \\
\hline Artemisio-Agropyrion intermedii & 0.00 & 0.00 & 0.03 & 0.00 & 0.00 & 0.00 & 0.00 & 0.00 \\
\hline Sisymbrietalia s.l. & 0.12 & 0.00 & 0.03 & 0.00 & 0.01 & 0.00 & 0.00 & 0.00 \\
\hline Onopordetalia & 0.04 & 0.00 & 0.00 & 0.00 & 0.00 & 0.00 & 0.00 & 0.00 \\
\hline Chenopodietea s.l. & 1.43 & 1.01 & 1.37 & 0.60 & 0.12 & 0.09 & 0.13 & 0.08 \\
\hline Artemisietea & 0.00 & 0.00 & 0.00 & 0.00 & 0.00 & 0.00 & 0.00 & 0.00 \\
\hline Artemisietalia & 0.00 & 0.00 & 0.00 & 0.00 & 0.00 & 0.00 & 0.00 & 0.00 \\
\hline Arction lappae & 1.08 & 0.89 & 1.61 & 0.68 & 1.45 & 0.17 & 0.40 & 0.09 \\
\hline Artemisietalia s.l. & 1.08 & 0.89 & 1.61 & 0.68 & 1.45 & 0.17 & 0.40 & 0.09 \\
\hline Artemisietea s.l. & 1.08 & 0.89 & 1.61 & 0.68 & 1.45 & 0.17 & 0.40 & 0.09 \\
\hline Galio-Urticetea & 0.00 & 0.00 & 0.00 & 0.00 & 0.00 & 0.00 & 0.00 & 0.00 \\
\hline Calystegietalia sepium & 0.00 & 0.00 & 0.00 & 0.00 & 0.00 & 0.00 & 0.00 & 0.00 \\
\hline Galio-Alliarion & 2.46 & 3.95 & 4.05 & 3.59 & 1.60 & 0.82 & 1.16 & 0.39 \\
\hline Calystegion sepium & 7.15 & 2.96 & 2.82 & 2.24 & 1.66 & 0.32 & 0.39 & 0.23 \\
\hline Calystegietalia sepium s.l. & 9.61 & 6.91 & 6.87 & 5.83 & 3.26 & 1.14 & 1.55 & 0.62 \\
\hline Galio-Urticetea s.l. & 9.61 & 6.91 & 6.87 & 5.83 & 3.26 & 1.14 & 1.55 & 0.62 \\
\hline Bidentetea & 0.00 & 0.00 & 0.00 & 0.00 & 0.00 & 0.00 & 0.00 & 0.00 \\
\hline Bidentetalia & 1.33 & 0.54 & 1.19 & 0.21 & 0.14 & 0.05 & 0.12 & 0.02 \\
\hline Bidention tripartiti & 0.24 & 0.01 & 0.29 & 0.00 & 0.03 & 0.00 & 0.04 & 0.00 \\
\hline Bidentetalia s.l. & 1.57 & 0.55 & 1.48 & 0.21 & 0.17 & 0.05 & 0.16 & 0.02 \\
\hline Bidentetea s.l. & 1.57 & 0.55 & 1.48 & 0.21 & 0.17 & 0.05 & 0.16 & 0.02 \\
\hline Plantaginetea & 0.00 & 0.00 & 0.00 & 0.00 & 0.00 & 0.00 & 0.00 & 0.00 \\
\hline Plantaginetalia majoris & 0.83 & 0.17 & 0.35 & 0.05 & 0.07 & 0.02 & 0.03 & 0.01 \\
\hline Agropyro-Rumicion crispi & 0.05 & 0.03 & 0.00 & 0.00 & 0.00 & 0.00 & 0.00 & 0.00 \\
\hline Plantaginetalia majoris s.l. & 0.88 & 0.20 & 0.35 & 0.05 & 0.07 & 0.02 & 0.03 & 0.01 \\
\hline
\end{tabular}


Kitaibelia 25(1): 57-78.

\begin{tabular}{|l|cccc|cccc|}
\hline \multicolumn{1}{|c|}{ Szüntaxon } & \multicolumn{4}{c|}{ Csoportrészesedés } & \multicolumn{4}{c|}{ Csoporttömeg } \\
& P-Szk & P-Cs & P-Msz & U-Cs & P-Szk & P-Cs & P-Msz & U-Cs \\
\hline Plantaginetea s.l. & 0.88 & 0.20 & 0.35 & 0.05 & 0.07 & 0.02 & 0.03 & 0.01 \\
Epilobietea angustifolii & 0.00 & 0.00 & 0.00 & 0.00 & 0.00 & 0.00 & 0.00 & 0.00 \\
Epilobietalia & 5.17 & 4.66 & 4.20 & 4.10 & 2.02 & 1.46 & 1.30 & 0.83 \\
Epilobion angustifolii & 0.00 & 0.45 & 0.42 & 0.05 & 0.00 & 0.05 & 0.06 & 0.01 \\
Epilobietalia s.l. & 5.17 & 5.11 & 4.62 & 4.15 & 2.02 & 1.51 & 1.36 & 0.84 \\
Epilobietea angustifolii s.l. & 5.17 & 5.11 & 4.62 & 4.15 & 2.02 & 1.51 & 1.36 & 0.84 \\
Urtico-Sambucetea & 0.00 & 0.00 & 0.00 & 0.00 & 0.00 & 0.00 & 0.00 & 0.00 \\
Sambucetalia & 0.00 & 0.00 & 0.00 & 0.00 & 0.00 & 0.00 & 0.00 & 0.00 \\
Sambuco-Salicion capreae & 0.37 & 0.40 & 0.10 & 0.39 & 0.04 & 0.59 & 0.01 & 0.33 \\
Sambucetalia s.l. & 0.37 & 0.40 & 0.10 & 0.39 & 0.04 & 0.59 & 0.01 & 0.33 \\
Urtico-Sambucetea s.l. & 0.37 & 0.40 & 0.10 & 0.39 & 0.04 & 0.59 & 0.01 & 0.33 \\
Chenopodio-Scleranthea s.l. & 21.42 & 16.73 & 19.29 & 13.64 & 7.41 & 4.06 & 5.30 & 2.29 \\
Indifferens & 3.60 & 3.89 & 5.06 & 2.88 & 3.66 & 2.48 & 6.02 & 0.76 \\
Adventiva & 8.84 & 8.68 & 13.13 & 8.24 & 9.64 & 9.41 & 15.80 & 6.52 \\
\hline
\end{tabular}

5. táblázat Szociális magatartási típusok aránya

Table 5 Percentage of social behaviour types (SBT)

P-Szk: Senecioni sarracenici-Populetum albae, Szigetköz (Kevey 2008: 25 felv.)

P-Cs: Senecioni sarracenici-Populetum albae, Csepel-sziget (KEVEY \& HuszáR 1999: 10 felv.; Kevey ined.: 15 felv.) P-Msz: Senecioni sarracenici-Populetum albae, Mohácsi-sziget (Kevey 2017: 25 felv.) U-Cs: Scillo vindobonensis-Ulmetum, Csepel-sziget (Kevey ined.: 12 felv.)

\begin{tabular}{|c|c|c|c|c|c|c|c|c|}
\hline & \multicolumn{4}{|c|}{ Csoportrészesedés } & \multicolumn{4}{c|}{ Csoportömeg } \\
\cline { 2 - 9 } & P-Szk & P-Cs & P-Msz & U-Cs & P-Szk & P-Cs & P-Msz & U-Cs \\
\hline S 6 & 5.63 & 9.61 & 8.03 & $\mathbf{8 . 5 6}$ & 2.11 & 10.37 & 5.26 & 12.80 \\
C 5 & 12.35 & 12.22 & 12.21 & 9.02 & 43.87 & 38.89 & 43.58 & 31.72 \\
G 4 & 32.29 & 36.56 & 25.92 & 44.32 & 24.94 & 30.96 & 15.15 & 42.36 \\
NP 3 & 0.00 & 0.00 & 0.00 & 0.00 & 0.00 & 0.00 & 0.00 & 0.00 \\
DT 2 & 34.79 & 25.44 & 29.60 & 24.11 & 18.25 & 8.00 & 16.40 & 4.84 \\
W 1 & 5.63 & 7.33 & 9.95 & 5.44 & 1.15 & 2.35 & 3.70 & 1.27 \\
I -1 & 1.64 & 2.78 & 4.68 & 3.42 & 0.63 & 0.84 & 9.08 & 3.99 \\
A -1 & 0.00 & 1.35 & 1.17 & 0.00 & 0.00 & 3.18 & 0.68 & 0.00 \\
RC -2 & 0.47 & 0.17 & 1.17 & 0.16 & 0.04 & 0.02 & 0.12 & 0.02 \\
AC -3 & 7.19 & 4.55 & 7.27 & 4.98 & 9.01 & 5.39 & 6.03 & 3.02 \\
\hline Val & $\mathbf{2 . 7 7}$ & $\mathbf{3 . 0 5}$ & $\mathbf{2 . 5 8}$ & $\mathbf{3 . 0 9}$ & $\mathbf{3 . 4 0}$ & $\mathbf{3 . 7 5}$ & $\mathbf{3 . 1 9}$ & $\mathbf{4 . 0 3}$ \\
\hline
\end{tabular}

